NBER WORKING PAPER SERIES

\title{
THE RISE AND FALL OF THE DOLLAR, OR WHEN DID THE DOLLAR REPLACE STERLING AS THE LEADING INTERNATIONAL CURRENCY?
}

\author{
Barry Eichengreen \\ Marc Flandreau \\ Working Paper 14154 \\ http://www.nber.org/papers/w14154
NATIONAL BUREAU OF ECONOMIC RESEARCH
1050 Massachusetts Avenue
Cambridge, MA 02138
July 2008

University of California, Berkeley and Graduate Institute of International Studies, respectively. This draft was prepared for the conference in honor of Peter Temin, Cambridge, May 9th, 2008. A longer version, available on request, was presented to the Past, Present and Policy Panel, Genoa, Italy, 28-29 March 2008. For financial support we thank the National Science Foundation, the France-Berkeley Fund, and the Committee on Research of the University of California, Berkeley. For assistance with collecting the data we indebted to Walter Antonowicz, Benrhard Mussak, Pedro Carvalho, Rui Pedro Esteves, David Schindlower, David Merchan Cardenas, Mauricio Cardenas, Thomas Holub, Hans Kryger Larsen, Vappu Ikonen, Olivier Accominotti, Filippo Cesarano, Mariko Hatase, Corry van Renselaar, Leif Alendal, Oyvind Eitrheim, Virgil Stoenescu, Mrs. Blejan of the Romanian Central Bank, Pilar Nogues Marco, Lars Jonung and Patrick Halbeisen. The views expressed herein are those of the author(s) and do not necessarily reflect the views of the National Bureau of Economic Research.

NBER working papers are circulated for discussion and comment purposes. They have not been peerreviewed or been subject to the review by the NBER Board of Directors that accompanies official NBER publications.

(C) 2008 by Barry Eichengreen and Marc Flandreau. All rights reserved. Short sections of text, not to exceed two paragraphs, may be quoted without explicit permission provided that full credit, including (c) notice, is given to the source. 
The Rise and Fall of the Dollar, or When Did the Dollar Replace Sterling as the Leading International Currency?

Barry Eichengreen and Marc Flandreau

NBER Working Paper No. 14154

July 2008

JEL No. F0,F33,N1,N2

\begin{abstract}
We present new evidence on the currency composition of foreign exchange reserves in the 1920s and 1930s. Contrary to the presumption that the pound sterling continued to dominate the U.S. dollar in central bank reserves until after World War II, we show that the dollar first overtook sterling in the mid-1920s. This suggests that the network effects thought to lend inertia to international currency status and to create incumbency advantages for the dominant international currency do not apply in the reserve currency domain. Our new evidence is similarly incompatible with the notion that there is only room in the market for one dominant reserve currency at a point in time. Our findings have important implications for our understanding of interwar monetary history but also for the prospects of the dollar and the euro as reserve currencies.
\end{abstract}

Barry Eichengreen

Department of Economics

University of California

549 Evans Hall 3880

Berkeley, CA 94720-3880

and NBER

eichengr@econ.Berkeley.edu

Marc Flandreau

Graduate Institute of International and Developmen

Rue de Lausanne 132

Geneva 21

Switzerland

flandreau@ ofce.sciences-po.fr 


\section{Introduction}

Much as Paul David described the invention of the mechanical typewriter - it was invented 51 times before being patented by Christopher Sholes in 1867, licensed to the Remington Company and successfully commercialized - the connections between the goldexchange standard and the Great Depression have been discovered repeatedly. They were discovered by Ehsan Choudhri and Levis Kochin in a seminal article in 1980. ${ }^{2}$ They were discovered by Barry Eichengreen and Jeffrey Sachs in articles published in 1985 and 1986. ${ }^{3}$ They were discovered by James Hamilton in an insightful article published in $1988 .{ }^{4}$ They were discovered by Peter Temin in his Robbins Lectures published in 1989. ${ }^{5}$ They were discovered by the now chairman of the Federal Reserve Board in his 1994 Journal of Money Credit and Banking Lecture. ${ }^{6}$ Moreover, these contributors to the contemporary literature had important antecedents, including Robert Triffin in the 1950s, Ragnar Nurkse in the 1940s, and Leo Pasvolsky in the 1930s. ${ }^{7}$

And yet, despite the long lineage of the literature, there remain important unanswered questions about the interwar gold-exchange standard. One such question, on which we focus in this paper, is what happened to the currency composition of international reserves. The interwar period was marked by the rise of New York as a financial center, rivaling London, and of the dollar as an international currency, rivaling sterling. The question is when the dollar overtook sterling as the leading currency in which to hold foreign exchange reserves. This answer is of historical interest. Tracking the positions of sterling and the dollar as reserve currencies opens a window onto international currency status more generally. It sheds light on the competition for financial-status between London and New York. Evidence on the liquidation of dollar and sterling reserves by foreign central banks and governments helps to identify the sources of deflationary pressure on the U.S. and British economies and hence helps to explain the propagation of the Great Depression. Finally. it may be possible to mine this episode for information about the circumstances in which, in the not too distant future, the euro might dethrone the dollar as the leading reserve currency.

The challenge of addressing these issues is that the currency composition of foreign exchange reserves in the 1920s and 1930s is a statistical black hole. Central banks published figures for total gold and foreign exchange reserves, information which was then compiled by the Bank for International Settlements and League of Nations, but not on the currency composition of those reserves. Estimates of that currency composition are sparse, undocumented and conflicting. In 1928 the Federal Reserve Board conjectured that "perhaps as much as $\$ 1,000,000,000$ of the operating reserves of foreign central banks" was held in the form of dollar balances, bills and bonds. ${ }^{8}$ Global foreign exchange reserves being on the order of $\$ 2.1$ billion

\footnotetext{
${ }^{2}$ Although Choudhri and Kochin did not much emphasize the foreign exchange component of the gold-exchange standard. See Choudhri and Kochin (1980).

${ }^{3}$ Eichengreen and Sachs $(1985,1986)$.

${ }^{4}$ Hamilton (1988).

${ }^{5}$ Temin (1989).

${ }^{6}$ Bernanke (1995).

${ }^{7}$ References are to Triffin (1960), Nurkse (1944) and Pasvolsky (1933). We talk more about the development of the literature in Section 2 below.

${ }^{8}$ As of June 1927. Federal Reserve Bulletin (1928), p.392. This was not an isolated opinion; at least some contemporaries saw things similarly. Thus, Mlynarski (1929, p. 66) claimed there was undisputed U.S. pre-
} 
(and assuming that a small but nonneglible fraction of foreign exchange reserves was held in third currencies), this implies that the dollar had already overtaken sterling as the leading reserve currency in the second half of the 1920s. Subsequently, Triffin (1968) offered a sharply contrasting estimate for 1928, namely that sterling's share of global foreign exchange reserves was on the order of 80 per cent. Even more strikingly, he estimated that sterling's share remained around 70 per cent in 1938. Others like Aliber (1968) and, more recently, Chinn and Frankel (2008), have built on the work of Triffin and others, suggesting that dollar only overtook sterling after World War II. This is seen as testifying to the advantages of incumbency and to the power of network effects, which create inertia in the currency composition of foreign exchange holdings and leave room in the market for only one dominant international currency. ${ }^{9}$

These estimates for the 1920s and 1930s are based on fragmentary evidence and conjecture. Triffin's estimates, which are probably the most widely cited, are undocumented and unexplained. For more than 70 years, then, scholars have made the "capital mistake" of theorizing about the currency composition of foreign exchange reserves in advance of the facts. ${ }^{10}$

In this paper we partially fill this gap. We report new estimates of the currency composition of foreign exchange reserves in the 1920s and 1930s. These estimates are based on data gleaned the archives of central banks. Inevitably there are gaps, but our estimates cover some 80 per cent of global foreign exchange reserves.

Our new estimates are at variance with previous pictures. We find that the dollar first overtook sterling as the leading reserve currency not in 1928, 1938 or 1948 but in the mid-1920s, and that it then widened its lead in the second half of the decade. Evidently incumbency and inertia did not delay the transfer of leadership for as long as suggested by Triffin, Chinn and Frankel. Then, however, with the devaluation of the dollar in 1933, sterling regained its place as the leading reserve currency. ${ }^{11}$ Contrary to much of the literature on reserve currency status, it does not appear that dominance, once lost, is gone forever. ${ }^{12}$

Our evidence for the 1920s and 1930s is also inconsistent with the notion that there is only room for one dominant reserve currency, along perhaps with a competitive fringe of minor players, owing to the network externalities thrown off by the dominant currency. ${ }^{13}$ A plausible reading of our evidence is that sterling and the dollar shared reserve currency status, more or less equally depending on year, for much of the interwar period. The prewar oligopoly described by

eminence during the late 1920s. The relative decline of London during the 1920s is also ascertained by Coste (1932). Nathan (1938) sides with Coste. BIS (1932, p.17) argues that the US dollar must have been a reserve currency of choice during the 1920s, because reserve holdings originated in dollar-denominated credits. Commenting on the causes of the increase in foreign exchange holdings in Europe during the late 1920s, it points out to the driving role of one single country (France), but beyond it emphasizes the role of "the credits granted by America to the European debtor countries in the years 1927-1930 (to some extent also to the credits granted by Great Britain, Switzerland and Holland) [...] The foreign exchange proceeds of these credits found their way into the portfolios of the European Central Banks, to the extent to which they were not employed for import purposes (either immediately or after contribution to an expansion of credit), thus forming the basis for a parallel credit expansion and a parallel development of the trade cycle in America and in Europe.”

${ }^{9}$ As modeled by Krugman (1984).

${ }^{10}$ To paraphrase Sherlock Holmes.

${ }^{11}$ Hence "the rise and fall of the dollar" in our title.

${ }^{12}$ Note also that these findings dissolve some of the conflict between the Federal Reserve and Triffin: the Fed was right about dollar dominance in the 1920s, Triffin was right about sterling dominance in the 1930s. (Though Triffin got 1928 wrong.)

${ }^{13}$ To adopt some terminology for oligopoly theory. Network externalities as an argument for persistence has a venerable tradition in international monetary economics; see Kindlberger (1967), Krugman (1984), Kiyotaki and Wright (1989). Flandreau and Jobst (2006) provide a survey and empirical evidence. 
Lindert (1969), where market share was split between sterling, the French franc and the mark, was displaced by a sterling-U.S. dollar duopoly.

The body of the paper is organized as follows. Section 2 provides some background on the evolution, operation and literature on the gold-exchange standard. In Section 3 we describe our data and methods and in Sections 4 and 5 our findings. Section 6 then draws out additional implications for interwar monetary history, focusing on earlier literatures on sterling and the dollar as international currencies more generally.

\section{Genoa and Beyond}

In what remains the single most important scholarly work on the gold standard before 1913, Arthur Bloomfield (1963) described the practice of holding external reserves in convertible foreign assets. Bloomfield classified Russia, Japan, Austria-Hungary, Belgium, the Netherlands, Canada, South Africa, Australia, New Zealand and most of Scandinavia all as on some form of gold-exchange standard - that is, as holding a substantial part or the bulk of their external reserves in foreign exchange. He distinguished the Bank of Finland, the Swedish Riksbank and the National Bank of Belgium, which held the majority of their external assets in the form of foreign bills, balances with foreign correspondents and foreign bonds, from the Russian State Bank, the Bank of Norway, the Bank of Japan and the Austro-Hungarian bank, which held smaller but still substantial shares of their external assets in this form. ${ }^{14}$ He observed that currency boards could also reasonably be placed under this heading, in that they held their currencies rigid not against gold but against an external numéraire currency that was in turn pegged to gold, while the backing for the domestic currency was exclusively in the form of interest-bearing convertible external assets. Economies in this category included Ceylon, India, Kenya, Malaya, the Maldives, Panama, the Philippines, Seychelles, and Singapore. ${ }^{15}$

Bloomfield understood the gold-exchange standard as a progressive development. As he portrayed it, there was a natural progression from gold coin standard to the gold bullion standard and then to the gold-exchange standard. Each step further economized on the real resource costs of operating the gold standard. Each step further limited the consumption that had to be foregone in order to obtain the yellow metal ultimately providing the basis for the domestic circulation, but without diminishing the credibility of the monetary standard.

The gold-exchange standard, as the final stage in this evolution, piggybacked on the development of international financial centers with strong financial institutions and liquid financial markets, where external reserves could be safely held and conveniently accessed. It was thus not surprising that economies with extensive commercial, financial and political links to those financial centers were disproportionately inclined to adopt the gold-exchange standard. Nor was it surprising that relatively poor countries, for which the opportunity cost of accumulating gold bullion was high, had the greatest tendency to economize on gold by holding their reserves in interest-bearing form.

Bloomfield's intellectual progeny, Peter Lindert (1969), described the further development of the gold exchange standard in the years leading up to World War I. Basing his work on the publications of central banks, governments and commercial banks, Lindert assigned

\footnotetext{
${ }^{14}$ Others such as Nurkse (1944) would have added Argentina to this list. A Bank of International Settlements memo on the Gold Exchange standard (BIS, 1932) describes India and Austro-Hungarian cases archetypal examples of the gold-exchange standard.

${ }^{15}$ This list is from the appendix to Schuler (1992).
} 
each institution's foreign reserves to a particular currency. ${ }^{16}$ He thereby constructed estimates of foreign exchange reserves for 1899 and 1913.

Lindert's estimates suggest that foreign exchange reserves accounted for about 20 per cent of the total gold and exchange reserves of central banks and governments on the eve of World War I, up from less than 10 per cent of total reserves in $1880 .^{17}$ They suggest that sterling was far-and-away the dominant reserve currency: 64 per cent of known official foreign exchange assets were held in London, while 15 per cent were held in Paris and 15 per cent were held in Berlin. ${ }^{18}$ Between 1899 and 1913 the mark's share remained unchanged, but the franc's share rose to 31 per cent at the expense of sterling's, which fell to 48 per cent. The rise in the franc's share had a lot to do with events in one country, Russia, which was on the receiving end of French lending and accumulated official balances in Paris in this period. ${ }^{19}$ The only other countries holding significant foreign exchange reserves in Paris, according to Lindert, were Italy and Greece. Canada was probably the only country to hold significant official foreign balances in New York. $^{20}$ More broadly, the growing geographical and currency diversification of foreign reserves reflected the tendency for other countries and financial centers to catch up to Britain and London, respectively. The trend can be viewed as strengthening the foundations of the goldexchange standard insofar as it relieved countries and central banks of the fears associated with holding all their official foreign-exchange eggs in one basket.

What this progressive portrayal leaves out is the greater fragility of the gold-exchange standard. The propensity to hold backing for the domestic circulation in the form of interestbearing assets in the major financial centers hinged on the perceived stability and liquidity of those balances, something that could be undermined by any number of events. War might lead belligerents to embargo gold exports and to seize the balances of an enemy power. Governments and central banks seeking to build up the domestic market as a reserve center might undermine the position of a competitor by liquidating (converting into gold) external assets held in its currency. Devaluation against gold, either actual or anticipated, by a reserve-center country would inflict losses on economies holding their external reserves in the form of interest-bearing assets in its market and discourage the practice.

\footnotetext{
${ }^{16}$ In this period foreign-exchange balances were typically booked together with other miscellaneous assets under the heading "other assets." It is thus conceivable that Lindert's estimates for the prewar period may overstate the extent of foreign-exchange holdings insofar as other items are included under "other assets.” Lindert himself observes that his estimates of prewar totals exceed significantly those of earlier scholars.

1714 per cent of the reserves of central banks and 21 per cent of the reserves of treasuries and exchange equalization funds.

${ }^{18}$ Lindert's figures also include a substantial unknown or unallocated portion.

${ }^{19}$ Flandreau (2003) argues that Russia's policy of holding balances abroad was a self-insurance device. Flandreau and Gallice (2003) study the books of one major recipient of Russian funds, the Banque de Paris et des Pays-Bas. They find that the French bank hedged it position by holding large amounts of sterling bills an illustration of the critical role of the London discount market even when foreign holdings in Paris were increasing.

${ }^{20}$ Through its Finance Ministry.
} 


\section{Figure 1. Gold and Foreign Exchange Reserves ( 24 countries, millions of US dollars)}

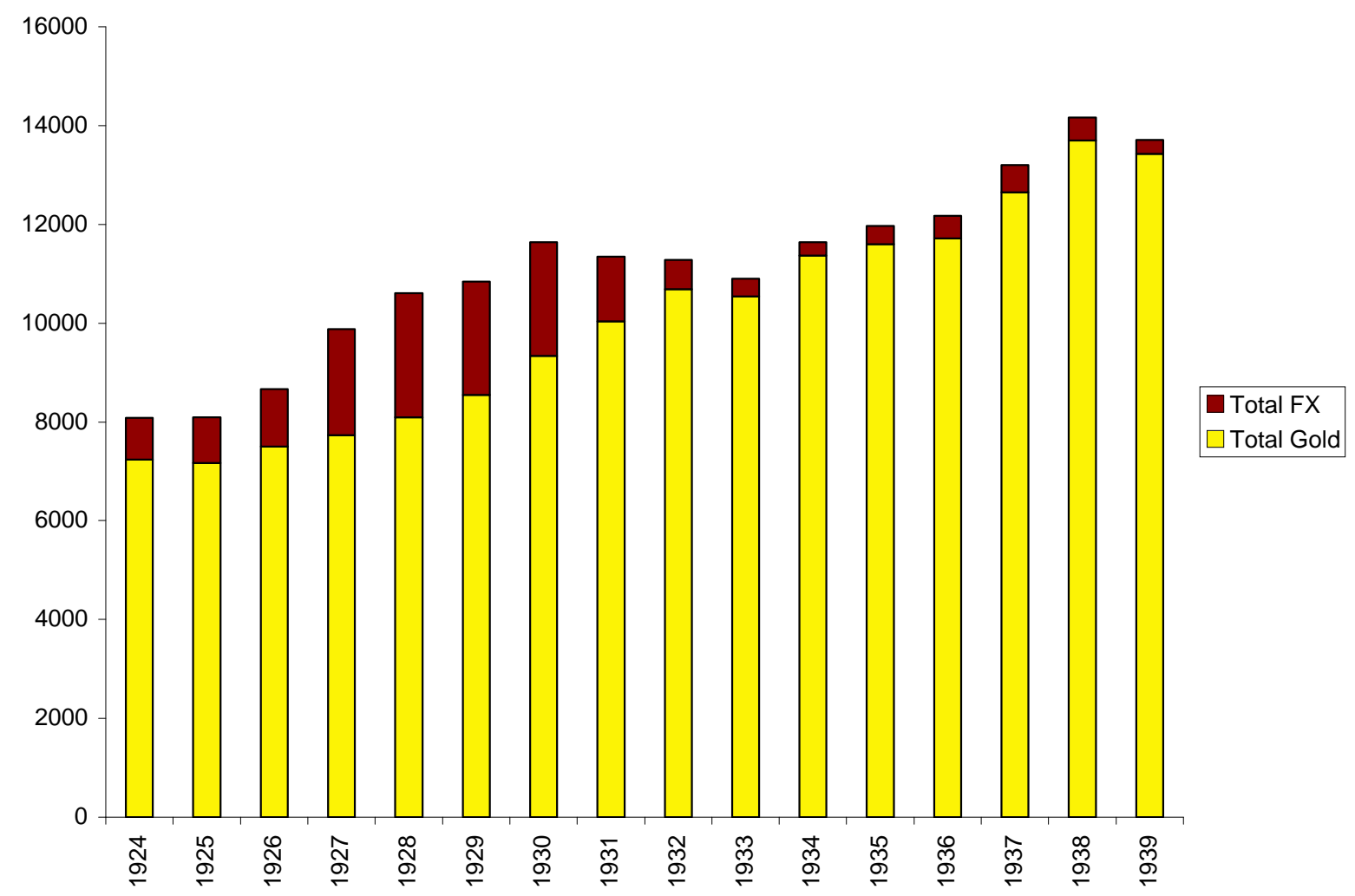

Source: Authors' estimates, based on Nurkse 1944 (gold and foreign exchange reserves pre-1932), Board of Governors of the Federal Reserve System (gold post 1932) and League of Nations Memoranda on Central Banks (foreign exchange reserves post 1932).

There were examples of each of these disruptions during and after World War I. Gold exports were embargoed. France curtailed its accumulation of foreign exchange reserves after 1928, something that some have seen as a reflection of its campaign to elevate Paris to the status of international financial center. ${ }^{21}$ The devaluation of sterling in 1931 inflicted losses on holders of sterling reserves, causing many them to liquidate their foreign currency holdings after the fact. $^{22}$ Thus, the share of foreign exchange in total reserves (as valued by the League of Nations) fell from 36 per cent in 1929-30 to 19 per cent in 1931 and just 8 per cent in 1932. (See Figure 1.) Given still-prevailing rules for backing domestic circulation with either gold or convertible foreign exchange, this collapse of the exchange component of global reserves placed deflationary pressure on the world economy at the worst possible time.

\footnotetext{
${ }^{21}$ E.g. Einzig (1931). In the toxic political climate of the interwar years, accusations that central banks made a strategic use of their foreign balances were pervasive. It is not hard to cite examples of the practice. In October 1929 Governor Emile Moreau of the Bank of France, in a letter to the French Minister of Finance, acknowledged that the conversion of sterling holdings by the Bank of France was aimed, in part, at weakening London and promoting the position of Paris as an international financial center.

${ }^{22}$ The Bank of France, not having been able to fully liquidate its sterling balances, was rendered technically bankrupt and had to be recapitalized with government help. Following this debacle it began liquidating its dollar reserves. Politically-sensitive observers suggested deeper motivations. In February 1932 Senator Carter Glass suggested that France's withdrawals were intended to influence U.S. reparations policy. Coste (1932), p. 205.
} 
But in the 1920s, when the interwar system was forged, these were still mostly problems for the future. ${ }^{23}$ Few contemporaries appreciated the intrinsic fragility of a system that pyramided a growing monetary circulation on an increasingly narrow base of gold and whose viability hinged on both economic and political stability and investor confidence. ${ }^{24}$ It was therefore cost efficiencies and not risks that dominated contemporary discussion and motivated the more widespread adoption of gold-exchange-standard practice.

The backdrop to these efforts was the rise in price levels in the period surrounding World War I. The Great War (like most wars) had been inflationary, as governments enlisted seigniorage in the national defense. Money creation and inflation were made possible by the suspension of gold convertibility or at least the temporary imposition of a de jure or de facto embargo on gold exports. Wartime inflation was only partially reversed by deflation in 1920-1. Higher prices, together with higher levels of production as the world economy resumed its growth, implied the need for larger stocks of money and credit.

The perceived problem was that the growth of global gold stocks had not kept pace with this need. Gold production had fallen steadily since 1915. And there was reason to think that this problem was likely to grow more serious if, as widely presumed, gold convertibility was restored on the basis of prewar parities. Prewar parities meant prewar domestic-currency prices of gold. This meant no increase in the nominal value of existing gold balances. And with only the price of gold back at 1913 levels (but other commodity prices remaining higher), the real price of gold and hence mining activity would be depressed.

There were two conceivable solutions to this problem. ${ }^{25}$ One was a generalized deflation to bring price levels back down, thereby raising the real price of gold back to where it could back a stock of real balances sufficient to support the prevailing level of economic activity in the short run and stimulate an adequate flow supply of newly mined gold to meet the monetary needs of an expanding world economy in the long run. Absent other steps, the restoration of gold convertibility at prewar parities would be enough to bring this about. Lower gold prices would mean less valuable monetary gold stocks, a smaller domestic circulation, and the credit stringency needed to induce the requisite deflation. The problem with this solution, as contemporaries understood, was that deflation could also mean slow economic growth. ${ }^{26}$

The alternative was to further institutionalize the prewar practice of supplementing gold with foreign exchange. This idea was famously advanced at the Genoa Conference in 1922. Ralph Hawtrey (Director of Financial Enquiries at H.M. Treasury) drafted on behalf of the

\footnotetext{
${ }^{23}$ This is not to say that the preference for supplementing gold with foreign exchange was impervious to events like the outbreak of the Boer War, the 1907 financial panic in the Unite States, the 1911-12 Moroccan crisis, or military action in the Balkans, in response to each of which there was a visible drop in the share of foreign exchange in external reserves. An earlier scholar emphasizing these connections is de Cecco (1974).

${ }^{24}$ French representatives at the Genoa conference had voiced concerns along these lines, although later research has questioned their concerns.

${ }^{25}$ That is to say, two solutions were conceivable to contemporaries. Looking back from a distance of 80 years, we can imagine still other solutions, such as no gold standard or restoration of the gold standard on the basis of higher domestic-currency gold prices all around. But these hypothetical solutions were beyond the imagination of contemporaries. See Temin and Vines (2008). At the time, however, those few who could imagine these additional solutions dismissed them as undesirable and counterproductive. Thus, Ralph Hawtrey, in a paper originally read in 1919, referred to the possibility of raising the price of gold as "hardly consistent with the preservation of public good faith.” Hawtrey (1923), p.56. The delegates to the Genoa Conference (see below) similarly rejected the notion of stabilization on the basis of higher gold prices as undermining confidence in the authorities' commitment to gold convertibility.

${ }^{26}$ See Keynes $(1923,1925)$.
} 
conference's financial commission a proposal for central banks to augment gold with foreignexchange reserves. The commission adopted a resolution authorizing central banks "in addition to any gold reserve held at home, [to] maintain in any other participating country [that had previously restored gold convertibility] reserves of approved assets in the form of bank balances, bills, short-term securities or other suitable liquid assets."27 It recommended revising central bank statutes to facilitate this practice. The principal reserve centers, for their part, were encouraged to restore free markets in gold as quickly as possible so that their financial assets, now freely convertible, would constitute an attractive supply of foreign reserves.

The Genoa resolutions, together with the general desire to avoid a more widespread deflation, had the desired effect. With the advice of the League of Nations, Austria, Danzig, Hungary, Bulgaria, Estonia and Greece all adopted new or revised statutes authorizing their central banks to hold the entirety of their external reserves in the form of foreign bills and balances. ${ }^{28}$ A long list of other central banks was authorized to hold a portion of their reserves in this form. ${ }^{29}$ And still other countries that had not yet established central banks held external reserves in the form of bills and balances through other government agencies. ${ }^{30}$

Thus, whereas foreign exchange had accounted for roughly 20 per cent of the total reserves of central banks and governments in 1913, by 1925 this ratio had reached 28 per cent. $^{31}$ (Again, see Figure 1.) By 1926 the ratio was 31 per cent. In 1927-28, the heyday of the interwar gold-exchange standard, it was 42 per cent. The share of reserves accounted for by foreign exchange then collapsed catastrophically.

A few qualifications are needed before proceeding. First, the British were more enthusiastic about the spread of the gold-exchange standard than the French and Americans. Not just Hawtrey, Keynes and Horne at Genoa but Montagu Norman all through the 1920s saw the gold-exchange standard as strengthening Britain's financial position. In contrast, the French and Americans inclined toward an idealized vision of the prewar system and plumped for a more heavily gold-based system. ${ }^{32}$ Insofar as different financial centers had influence with different

\footnotetext{
${ }^{27}$ Resolution 2, p.449.

${ }^{28}$ Of course, it could not be any kind of foreign bills. The statutes of the Austrian National Bank, for instance, stipulated that foreign values (Devisen) had to be understood to mean "bills of exchange made out of currencies not having undergone any violent fluctuations of exchange, which are payable at leading banking centres in Europe or America, and are vouched for by banking institutions of unquestioned solvency... Credit balances and cash deposits may also be regarded as foreign values if they are available at any time and held at leading banking centres in Europe or America at institutions of unquestioned solvency." Article 85 of the Austrian central bank's statutes, in League of Nations, 1930, Legislation on Gold, Geneva: League of Nations, p. 159.

${ }^{29}$ Nurkse's list includes Albania, Austria, Belgium, Olivia, Bulgaria, Chile, Colombia, Czechoslovakia, Denmark, Ecuador, Egypt, Estonia, Finland, Germany, Greece, Hungary, Italy, Latvia, Peru, Poland, Portugal, Romania, Spain, Uruguay, the USSR and Yugoslavia. Japan can also be placed under this heading, although it returned to the gold standard only very late and its foreign bills and balances were held not by the Bank of Japan but by the Yokohama Specie (as many of them also had been before 1913).

${ }^{30}$ India, New Zealand, Argentina and Venezuela among them.

${ }^{31}$ According to data for the 24 central banks canvassed by the League of Nations. (Nurkse 1944, Appendix II).

${ }^{32}$ The U.S. possessing ample gold, Benjamin Strong of the New York Fed did not anticipate that the world returning to a mainly gold-based system like that his own country had operated prior to 1913 necessarily augured further deflation. In any case, the United States, consistent with its stance toward the League of Nations, did not even attend the Genoa Conference. Some claim that French authorities, being in no position to restore gold convertibility, given France's turbulent politics and unstable finances, suspected that the proposal advanced by the British at Genoa was designed to elevate London over Paris as a financial center (Kooker 1976). But Paris was in no position to be a serious challenger to London anyway given London pre-war lead. Another view, articulated by influential economists and policy makers of the time, was that the gold-exchange standard fuelled inflation and lacked
} 
parts of the world, this difference of opinion influenced which countries were more and less inclined to hold foreign exchange reserves. ${ }^{33}$ Not surprisingly, the practice of holding foreignexchange reserves was particularly prevalent in the British Commonwealth and Empire and among Britain's other important trading partners. ${ }^{34}$ And, in turn, this played an important role in reserve-currency competition, as we show below.

The reserve-center countries did not themselves hold much in the way of foreign exchange. ${ }^{35}$ This was as it should be: the whole point of other countries backing their monetary circulations with liquid assets issued by the reserve centers was that the reserve centers backed those same assets (for them, liabilities) with gold into which those assets could be freely converted. Had the reserve centers similarly backed their liabilities with claims on other countries, the arrangement would have simply been one big Ponzi scheme - and it would have been recognized as such. ${ }^{36}$

The principal exception was France, which after 1928 aspired to reserve center status. In 1926-27 the Bank of France had acquired large amounts of foreign exchange as a result of intervening in the foreign exchange market to prevent the franc from appreciating excessively once the Poincaré stabilization had halted the country's high inflation. (Again, this is evident in Figure 1.) This foreign exchange was in excess of what the Bank of France needed to back its monetary liabilities once gold convertibility was restored in $1928 .{ }^{37}$ Its existence dismayed French officials, and their efforts to liquidate it created serious problems for the reserve centers and the world economy.

In addition the existence of these balances complicates comparisons between the prewar and interwar periods. One can argue that because France was a reserve center the Bank of France's foreign-exchange balances should be disregarded when one compares the prevalence of the gold-exchange standard before and between the wars, just as one can argue that one should disregard the substantial foreign exchange balances held by Germany and the very much smaller ones held by France before World War I.

But modifying the statistics in this way alters the broader picture only slightly. If we eliminate France from the League of Nations' figures (the U.S. and the U.K. already being omitted), the share of foreign exchange in the total external reserves of the remaining 23 countries falls to 38 per cent in 1927-28 (down from 42 per cent for all 24). If we similarly eliminate Britain, France and Germany from Lindert's figures for 1913, the share for the remaining 32 countries rises to 22 per cent (up from 19 per cent for all 35). The contrast between the two periods in the prevalence of the gold-exchange standard is then attenuated

\footnotetext{
discipline (Rist 1932). This latter view was given due consideration in international circles, especially as the unwinding of foreign currency balances in 1931 and the ensuing scramble for gold forced a painful downward adjustment (BIS 1932).

${ }^{33}$ Thus, for example, where the Bank of England took the lead in providing advice and finance to a country seeking to stabilize and go back onto the gold standard, it recommended authorizing the central bank in question to hold a substantial share of its reserves in foreign exchange (which it would presumably do in London).

${ }^{34}$ This was, in effect a continuation of the pre-war trends identified by de Cecco (1974).

${ }^{35}$ At least they did not hold foreign exchange sufficient to attract notice or to detract from confidence in the automatic convertibility into gold of their own currencies. This qualification is important because we have evidence that the Bank of England did hold foreign assets, such as French and U.S. bills and bonds. Similarly, the BIS (1932) reports zero or negligible foreign currency holdings for the USA until 1929. At that date they show 190 million Swiss francs, which is slightly more than the foreign exchange reserves of, say, Denmark, but only about 1.3 per cent of Federal Reserve gold holdings.

${ }^{36}$ As emphasized by contemporaries (viz. Mlynarski 1929).

${ }^{37}$ At that point Paris halted all further accumulation of foreign exchange.
} 
somewhat by these adjustments but far from eliminated. The growth of the foreign exchange share of international reserves was not simply a French phenomenon, in other words; it was global.

\section{Data and Methods}

Compared to the prewar period, the interwar period displays no substantial changes from the prewar period, neither regarding the mechanisms of foreign exchange holdings and transfers, nor on the range of products that were used. Readers are referred to earlier discussions (Lindert 1969, Flandreau and Gallice 2003) for details as well as to the appendix. "Foreign exchange" consisted in three main international financial instruments: foreign bills, foreign deposits and first class government securities. ${ }^{38}$

Several official compilations document the evolution of aggregate gold and aggregate foreign exchange reserves in the interwar years. BIS (1932) covers 1924-32. Its statistics are annual, except for 1931-32, for which it provides quarterly data. 26 European countries and the United States are included, and all data are in Swiss gold francs. ${ }^{39}$ Another widely cited source is Nurkse (1944), published under the auspices of the League of Nations. Nurkse's statistics are annual. They cover 24 European countries, the period 1924-32, and are in U.S. dollars. ${ }^{40}$

Nurkse's series appear to have been compiled from contemporary periodical sources. The League of Nations published information on gold and foreign exchange reserves in its annual Statistical Yearbooks and occasional Memoranda. ${ }^{41}$ These sources report data in local currency units. Another useful reference is the Monetary Statistics published by the Federal Reserve Board (1943), which seems to have been the source for or at least used a methodology very similar to Nurkse. ${ }^{42}$ It is also possible that the BIS is the source for some of Nurkse's tabulations. $^{43}$

As mentioned, none of these sources provides information on the currency composition of foreign exchange reserves. Central banks never published foreign currency holdings breakdowns. We know only one case, Italy, where a central bank has published the currency decomposition of its foreign exchange reserves, but in a later statistical retrospective only. ${ }^{44}$

\footnotetext{
38 . The BIS Report on the Gold Standard argued, curiously, that holdings of foreign bills would have not been as inflationary as deposits with individual banks. The League of Nations' Memoranda made an incomplete but courrageous attempt to distinguish among these various instruments

${ }^{39}$ Until its devaluation in 1935, the Swiss franc was a gold currency whose gold content was equivalent to that of the pre-1914 French franc (a result of the monetary standardization that prevailed under the 1865 Latin Union). It was the accounting unit of the BIS (see Einzig 1931).

${ }^{40}$ With which Swiss gold francs had a fixed parity until 1933.

${ }^{41}$ The League of Nations' Memoranda do not cover the period 1926-1928, nor do they say anything about currency composition. But they are useful for their recording of a breakdown of foreign exchange reserves. Before 1925 they provide data for "foreign accounts" and "foreign bills. After 1929 they also occasionally record "foreign government securities. Economists and statisticians at the League worked with official central bank returns but apparently also communicated with statisticians within central banks thus explaining their making a number of meaningful adjustments, which are another source of information. In addition, the Memoranda for the 1920s reflect an attempt at providing a unified framework for recording central banks' balance-sheets.

${ }^{42}$ They provide total gold holdings in US dollars. Federal Reserve Board (1943).

${ }^{43}$ Although Albania, the United States and the United Kingdom (no foreign exchange reserves) are included in the BIS's tables but not in those of the League of Nations. The Nurkse numbers actually improved the BIS numbers. This is suggested by the correction that was made for France for which foreign exchange holdings registered in 1926-7 with other items under the heading "divers" have been duly incorporated in the foreign exchange reserve. ${ }^{44}$ Banca d'Italia (1993), Tables 1-2; pp.51-64. Even in this case, the figures need to be reworked in order to replace, among other things, book values by market exchange rates. During the 1920s for instance, Italian foreign currency
} 
We have therefore attempted to retrieve data on the currency composition of foreign exchange reserves from the archives of central banks. Generally these are contained in handwritten or typewritten ledgers. They vary in whether the amounts they report are in domestic or foreign currency. A complication is that material from the archives does not always match the totals published by the BIS and League of Nations. This may reflect valuation practices: it is not always clear what exchange rates were used when the BIS and League reported the value of foreign exchange reserves in Swiss francs or dollars. ${ }^{45}$ It is possible that central banks, when publishing information on their foreign exchange reserves and reporting to the League of Nations, included only a subset of their reserves, for example "foreign exchange held for cover purposes" (that required as statutory backing for domestic liabilities) and not also "other foreign exchange." Or it is possible that they report not only their own reserves but also those held on behalf of other agencies of government. ${ }^{46}$

Where national sources and the League of Nations differ, we have taken the national sources as definitive. We have sought to value gold and foreign exchange reserves at market prices, something that was not always the practice of contemporary central banks. ${ }^{47}$ Table 1 below provides a summary of the information that we have succeeded in assembling to date. ${ }^{48}$ At this stage our efforts have produced data for 18 countries, albeit with gaps. In practice, for any given year we are able to include about 15 countries, encompassing Western Europe, Eastern Europe, Asia and Latin America. The central banks in question account for roughly 75 per cent of global foreign exchange reserves. Table 1 below provides a summary of the information that we have succeeded in assembling to date. ${ }^{49}$

reserve decomposition uses pre-war parities which are way out of line with actual market exchange rates. The other partial exception is the monthly material put out by the Brazil’s currency board 1927-1929.

${ }^{45}$ And, for that matter, what gold price was used when valuing gold.

${ }^{46}$ Suppose the central bank holds foreign exchange for the account of the government, perhaps because the Treasury has deposited foreign currency at the central bank intended for the service of the external debt. In such cases, like that of Japan, we show the data both ways (below).

${ }^{47}$ Initially, there appears to have been very little tendency to "mark to market" - that is, more than a few central banks continued to value gold and, often, foreign exchange reserves at the 1914 parity long after the pre-World War I gold standard had collapsed. This tendency, perhaps predictably, then tended to diminish over time. Our procedure, which maximizes comparability across countries, is to use market exchange rates throughout. By contrast no effort was made at adjusting the price of foreign securities to mark to market, since the number and type of securities held are typically not reported. In the end, of course, every national case raises special issues and requires special handling.

${ }^{48}$ Note that the members of the British Commonwealth such as Australia, New Zealand and Ireland are omitted here, since their political or monetary autonomy from Britain was limited. Archival materials confirm that their foreign exchange reserves were entirely in sterling. Adding them would only reinforce our picture of sterling making a comeback in the 1930s. Important foreign exchange holders for which we have not been able to get any material at all at this stage include Germany, Mexico, Canada and Argentina. For other countries (Belgium, Portugal), we have succeeded in identifying sources (more, as in the case of Portugal, more sources) but not yet completed the process of gathering and processing the data.

${ }^{49}$ Note that the members of the British Commonwealth such as Australia, New Zealand and Ireland are omitted here, since their political or monetary autonomy from Britain was limited. Archival materials confirm that their foreign exchange reserves were entirely in sterling. Adding them would only reinforce our picture of sterling making a comeback in the 1930s. Important foreign exchange holders for which we have not been able to get any material at all at this stage include Germany, Mexico, Canada and Argentina. For other countries (Belgium, Portugal), we have succeeded in identifying sources (more, as in the case of Portugal, more sources) but not yet completed the process of gathering and processing the data. 


\section{Global Results}

We start in Figure 2 with a snapshot of foreign exchange holdings in 1929, the "heyday" of the interwar gold-exchange standard. The 16 countries included there (France, Italy, Switzerland, Netherlands, Denmark, Finland, Norway, Sweden, Chile, Colombia, Brazil, Spain, Austria, Romania, Czechoslovakia and Japan) held a total of $\$ 1.9$ billion in exchange reserves. This is 82 per cent of Nurkse's global total for end 1929 and approximately 75 per cent of the global total, (given Nurkse's incomplete country coverage).

The picture leaves little room for doubt. As of 1929 there were essentially two reserve currencies, the dollar and sterling, which together accounted for some 97 per cent of global foreign exchange reserves. So much for the idea that there is only room in the market for a single reserve currency at any point in time.

Figure 2. Aggregate Foreign currency holdings in 1929: A Snapshot (16 countries)

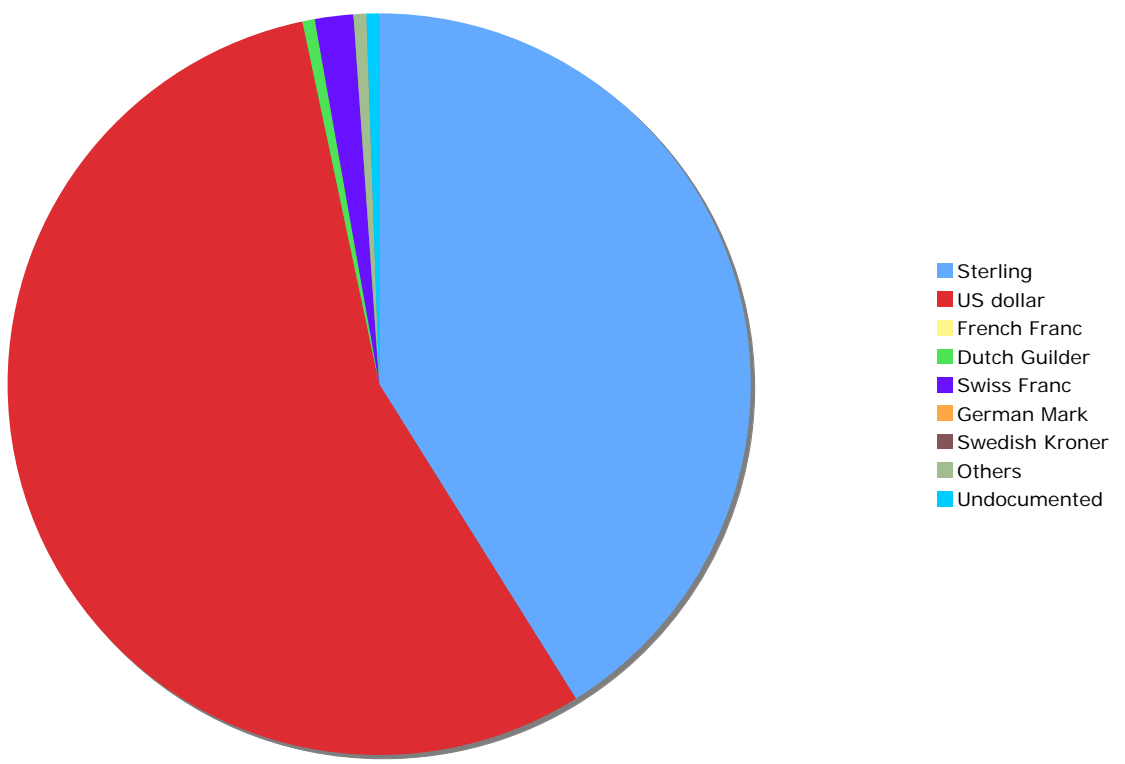

Source: See Text.

Other currencies pale in comparison. The Swiss franc and Dutch guilder, the two next most important currencies in central bank portfolios, totaled about 2 per cent of global exchange reserves. Also notable is the complete absence of the French franc. Although the franc was now credibly stabilized and backed by immensely large excess gold and foreign exchange reserves, it was surpassed even by the Swiss franc, the currency of a very much smaller country, as an instrument of foreign exchange reserves. To be fair, French francs would not be held as foreign exchange reserve by the Bank of France, which held about half of the world's foreign exchange. Even if one adjusts for this, by eliminating France's own reserves from the global total, francdenominated reserves still account for a mere two-tenths of one per cent of the global total. This gives a hollow ring to the literature on the challenge that Paris was mounting to the incumbent reserve-center countries. 
Figure 3

Decomposition of Reserves ( 4 countries)

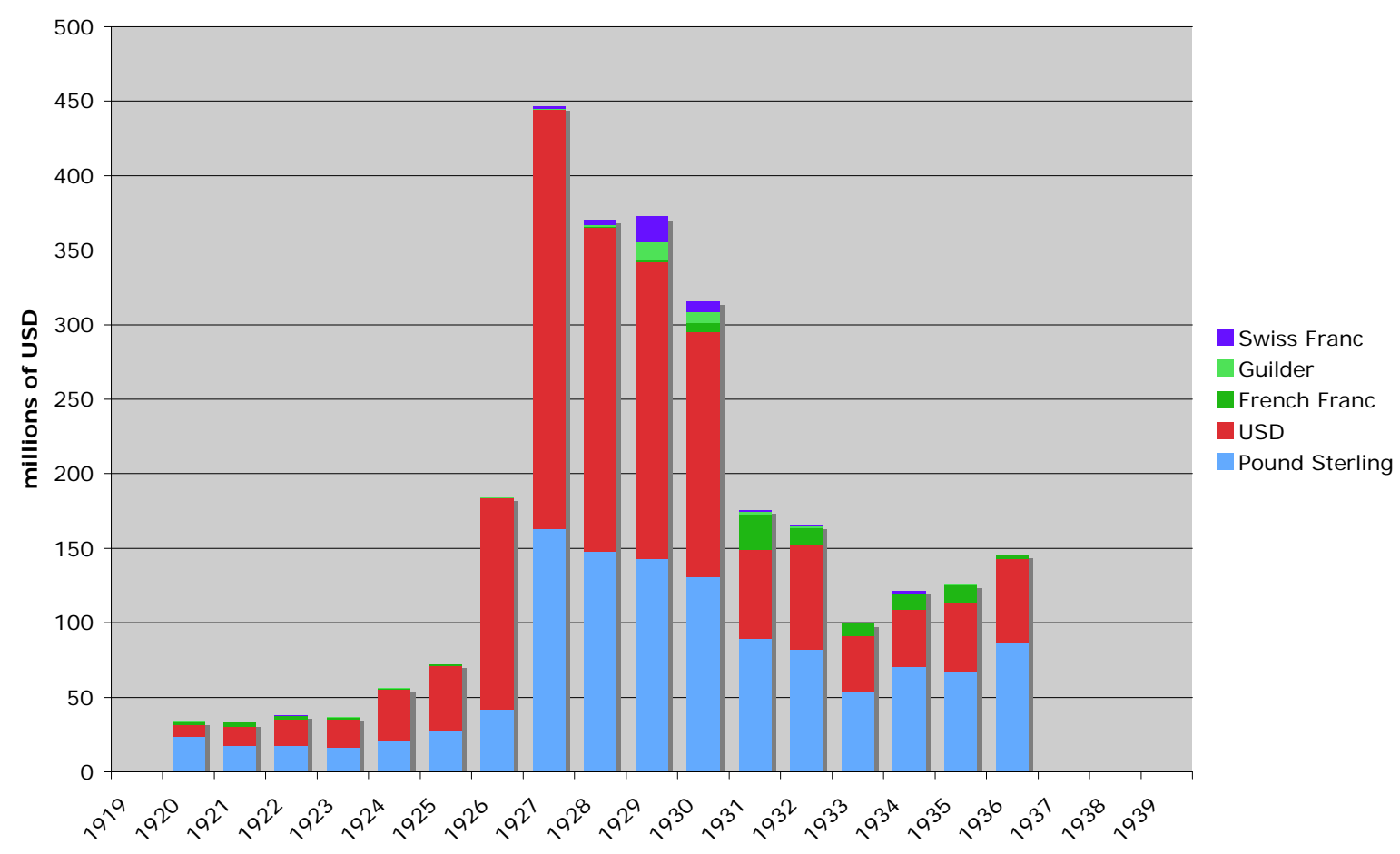

Source: see text.

Note also that our new estimates support the Federal Reserve Board conjecture for 1928 of approximately $\$ 1$ billion of dollar-denominated global exchange reserves (out of a roughly $\$ 2.3$ billion total) while contracting the suggestion by Triffin that sterling still accounted at that date for 80 per cent of global foreign exchange reserves. Thus, dollar supremacy so measured did not have to wait until after World War II, as has been repeatedly conjectured. ${ }^{50}$

Identifying the precise date at which the dollar overtook sterling is problematic, since information on the currency composition of foreign exchange reserves in the first half of the 1920s is more fragmentary. ${ }^{51}$ For four countries (Italy, Norway, Spain and Switzerland) we have a continuous run of currency-composition figures for the 1920s: as shown in Figure 3, these suggest that the dollar overtook sterling around 1924. The dollar then maintained its leadership

\footnotetext{
${ }^{50}$ We do not believe that adding additional countries will significant change this picture. The most important omission is Germany, which held less than one per cent of global foreign exchange reserves as of 1929. We suspect that it split them in fairly equal proportions between New York and London - or even held the bulk of those reserves in New York, given that the majority of German foreign borrowing in the 1920s was sourced in New York. Austria held more dollars than sterling (see below), and it is unlikely that Germany's behavior was significantly different. Next in order of importance in terms of missing countries is Belgium, which probably split is reserves not too unevenly between London and New York. (If it was a typical member of the gold bloc it would have held, say, 55 per cent of its exchange reserves in dollars and 45 per cent in pounds). On the other hand, the Belgians subsequently complained of the large capital losses suffered due to the depreciation of sterling in 1931, which may indicate larger reserve holdings. But the impact on our estimates would in any case be of second order importance, since Belgium foreign exchange reserves accounted for less than $1 / 2$ one of 1 per cent of the global total.

${ }^{51}$ Not surprisingly, given the chaotic political and financial circumstances of many countries in this period.
} 
through the second half of the 1920s, when sterling was continuously "under the harrow" - when there were persistent doubts about the ability of the Bank of England to maintain its convertibility. $^{52}$

For a somewhat larger group of countries (the previous four plus Czechoslovakia, Denmark, Finland, Japan, the Netherlands and Portugal), we can do the same thing starting in 1923. The result (Figure 4) suggests that the dollar overtook sterling as the leading reserve currency in 1924-26.

Figure 4. G10 Reserves

(Czechoslovakia, Denmark, Finland, Italy, Japan, Netherlands, Norway, Portugal, Spain, Switzerland)

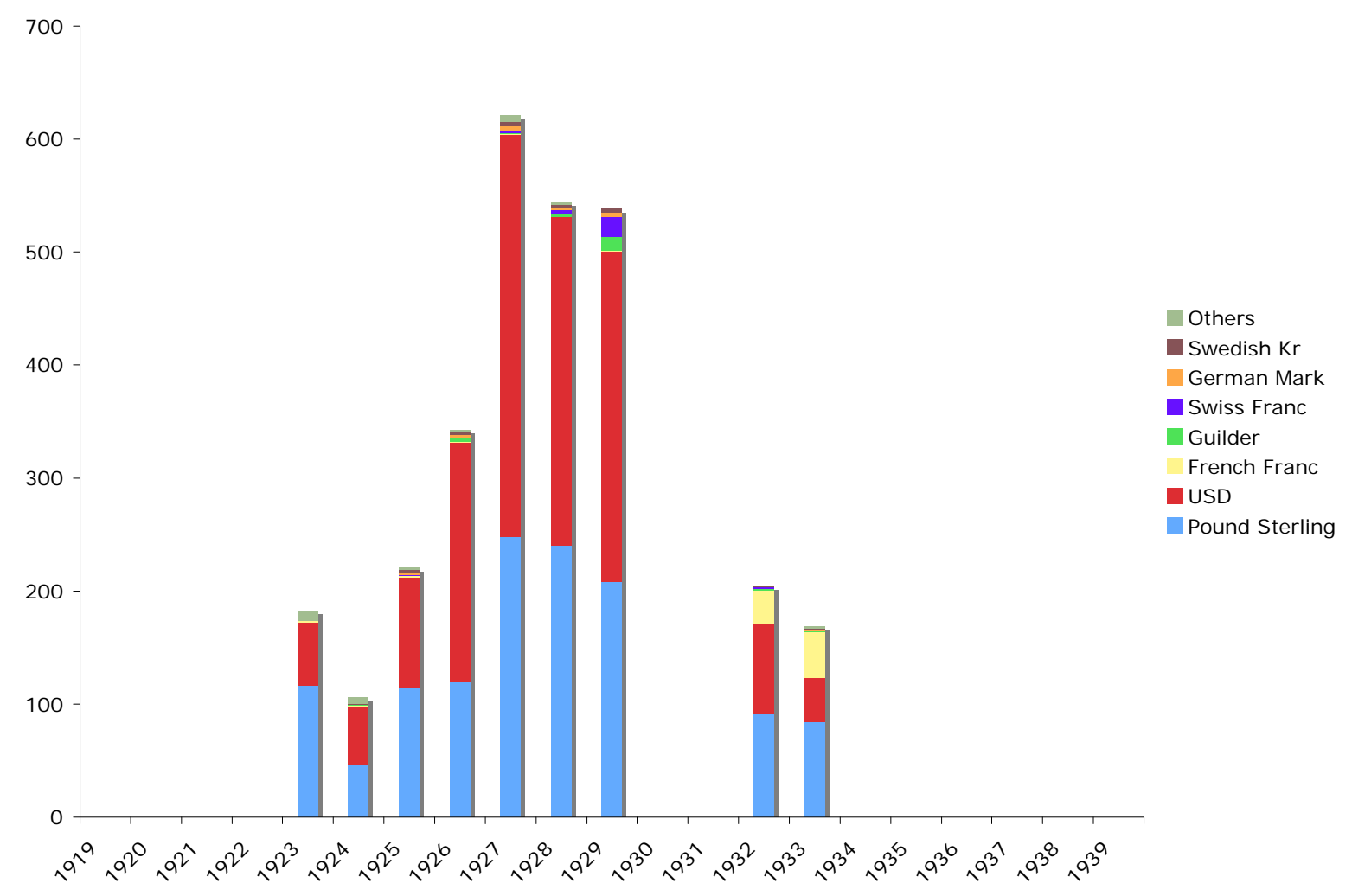

Finally, starting in 1928 we can add the Bank of France, at this time the single largest holder of foreign exchange reserves. Circa 1928 the French central bank still holds a slightly larger share of its foreign exchange reserves in sterling than in dollars (Figure 5). The sheer size of France's exchange reserves means that sterling temporarily regains its reserve-currency leadership as a result of the Bank of France's accumulation of London bills and balances. ("Regains" because France accumulated the vast majority of these balances only in late 1926 and 1927, so that whatever the currency composition of its existing reserves might have been earlier, adding them would not change the story.) From 1929 onward, however, the dollar is again dominant in French - and therefore global - reserves, as the Bank of France liquidates sterling

\footnotetext{
${ }^{52}$ The "under the harrow" quote is from Montagu Norman. Comments by the Governor of the Bank of France during the summer of 1929, quoted by Accominotti (2008), are indicative of the worries in a number of countries about the future of the pound, leading to the growing dominance of the dollar. Einzig (1931) disputes it but then he was an unrepentant supporter of sterling. We saw that future developments would vindicate his prejudices but at the time of his writing Einzig was deeply wrong.
} 
balances in exchange for gold. As always, the historical reality is complex. But the bottom line is unambiguous: the dollar overtook sterling as the leading reserve currency in the 1920s, not in the 1940 s or even 1950s.

Figure 5. France (millions of usd)

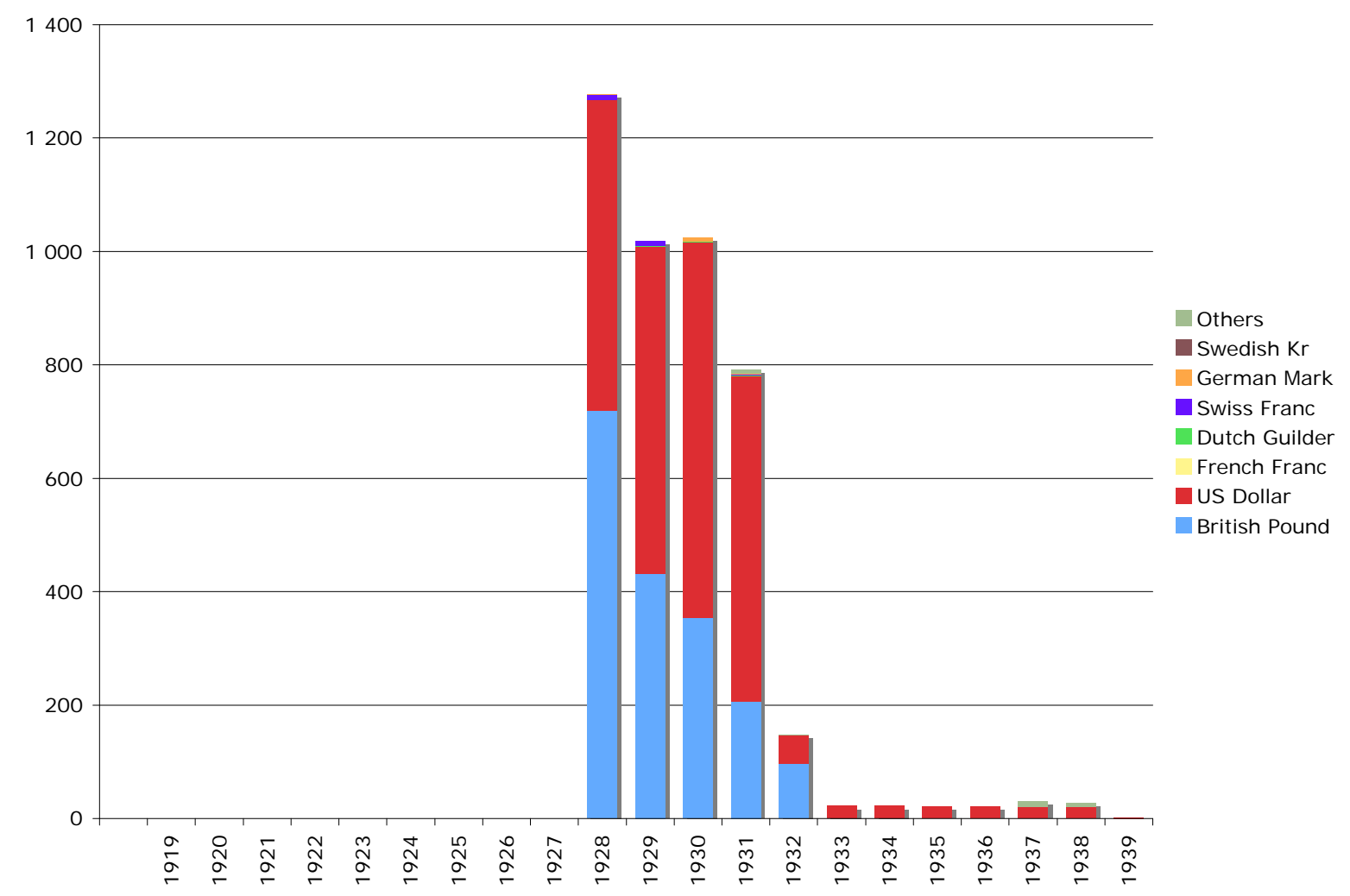

What about the 1930s? Another striking result is not just the liquidation of foreign exchange reserves and implosion of the gold-exchange standard, something that is already known on the basis of published aggregate foreign exchange reserves, but also the disproportionate liquidation of dollar reserves and the renewed relative dominance of sterling. At this point the Bank of France no longer figures in the story; by 1932 it has liquidated most of its dollar and sterling claims, and by 1933 it has liquidated these entirely but for a small residual dollar balance. In other countries, however, sterling regains its predominance relative to the dollar, a predominance that appears to be sustained for the remainder of the 1930s. Adding still other countries for which we have data for the 1930s (Ireland, Australia and New Zealand) only reinforces the picture, for these countries held the entirety of their reserves in pounds sterling.

Strikingly, then, the Federal Reserve's estimates of dollar dominance in the late 1920s and Triffin's conjecture of sterling dominance in the late 1930s were both correct. Why the compatibility of their conjectures has not been appreciated previously is also now evident: it is not always the case, it would appear, that the status as leading reserve currency, once lost, is necessarily lost forever.

But is sterling's recovery purely a matter of the sterling area? It is to this question that we now turn. 


\section{Regional Results}

We begin with the members of the gold bloc other than France (Figure 6). ${ }^{53}$ Here too there is evidence of the U.S. dollar establishing its dominance over the pound sterling in the 1920s and of that dominance increasing with time. However, all gold bloc countries began selling sterling in advance of the 1931 sterling crisis. Once that crisis erupted, however, the members of the gold bloc no longer distinguished sterling from the dollar, instead selling both. Thus, conventional accounts (e.g. Friedman and Schwartz 1963) describing how the sterling crisis led to a gold drain from the Federal Reserve and pressure on the dollar are on the mark.

Figure 6. Gold Bloc (ex France, millions of USD)

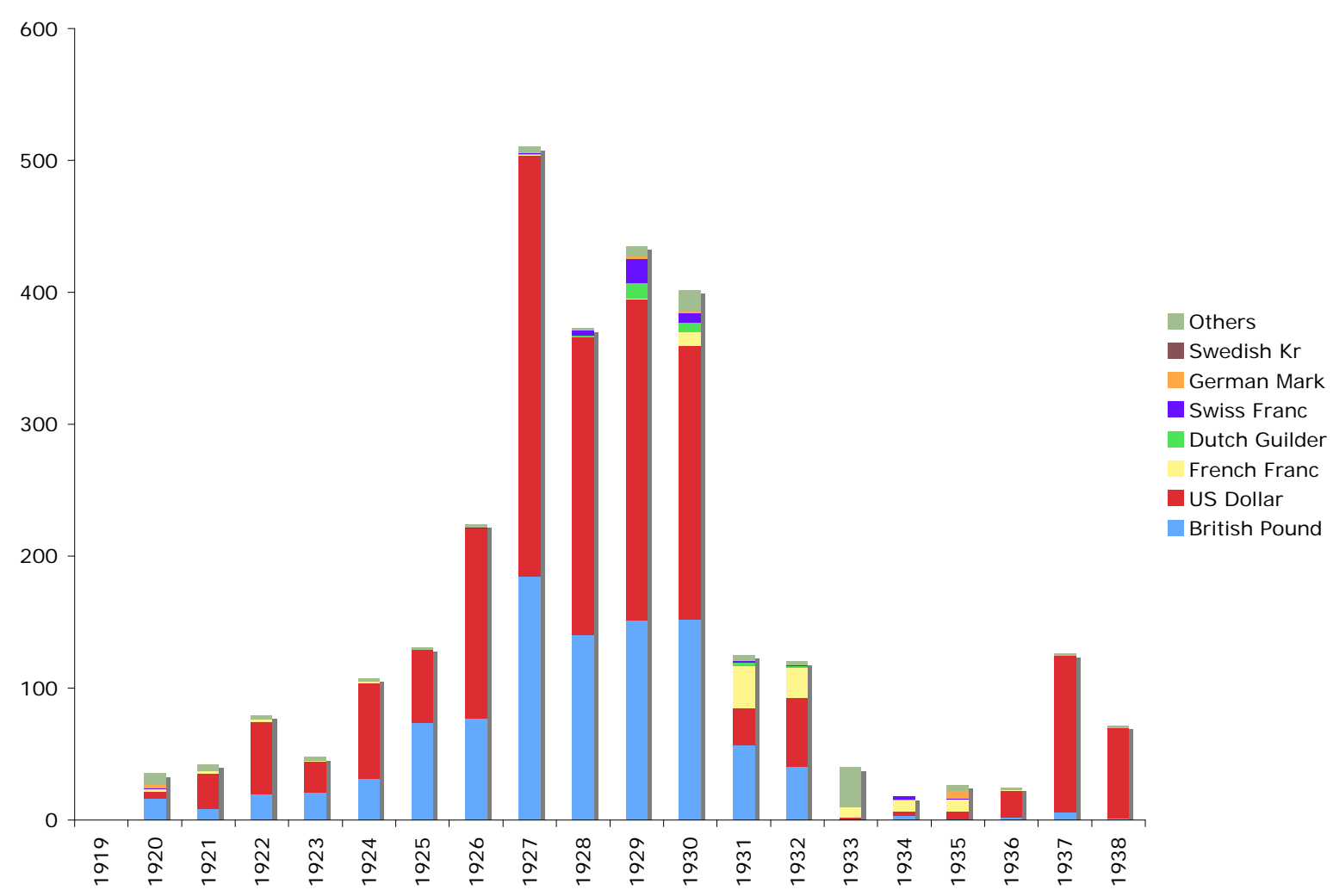

Note the relatively brief and modest increase of the role of the French franc in what became the gold-bloc countries ex-France. In the very early 1930s there was every reason to regard France, with its immense reserves and initially mild downturn, as a strong-currency country par excellence. There being no reason to believe that France would follow Britain in devaluing - in contrast to worries about possible devaluation by the United States - holding reserves in francs had attractions. But the florescence of the franc was brief. By 1934 there were growing questions about France's readiness to defend its existing gold parity. By that time the value of the French-franc-denominated reserves of the gold bloc were already in decline.

53 . This arrangement formed in 1933 and which comprised Belgium, France, Italy, Netherlands, Poland, Switzerland. In 1936 it was narrowed down to France, the Netherlands, Poland, and Switzerland. 


\section{Figure 7. Central European Exchange Reserves (Romania, Austria, and Czechoslovakia, millions of U.S. dollars)}

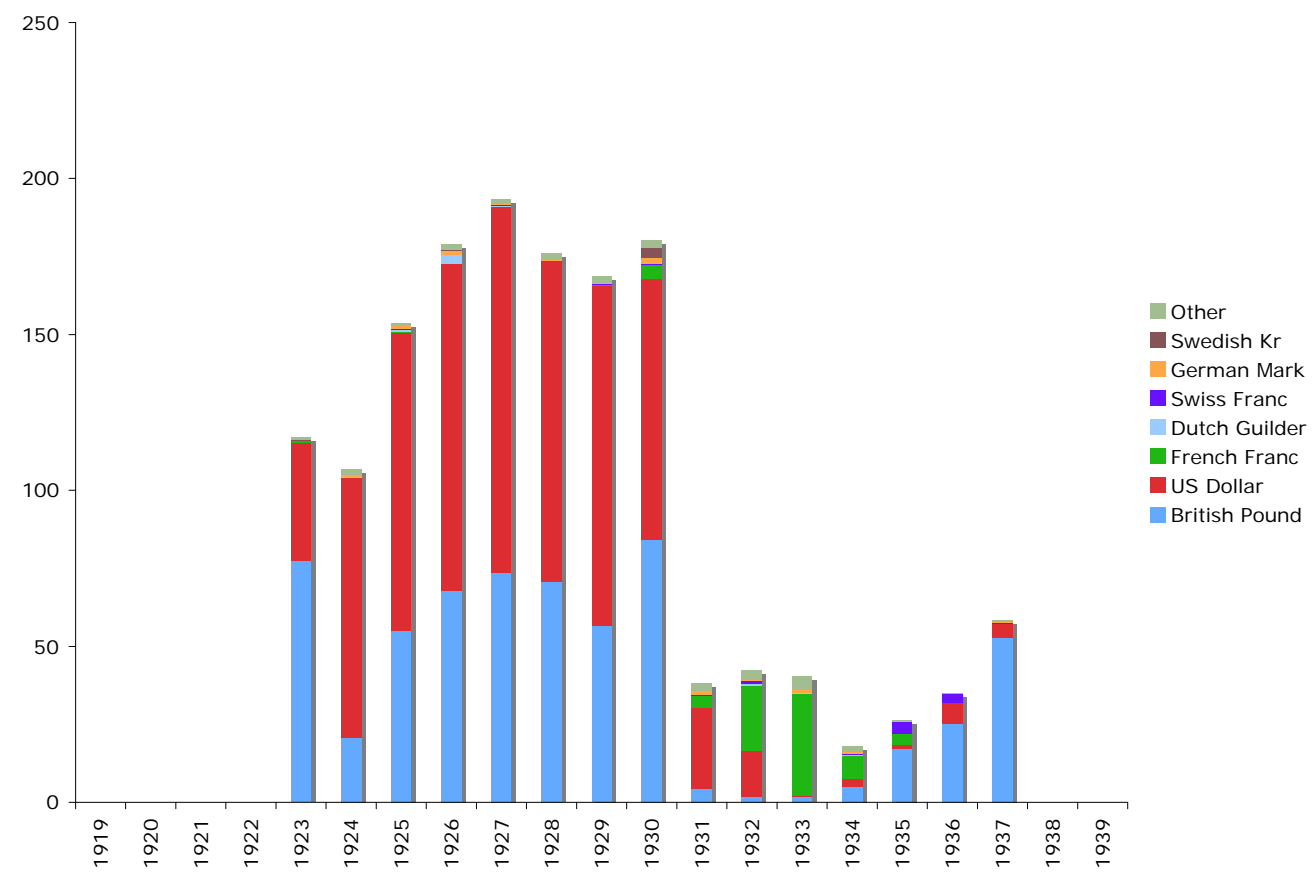

Source: Authors' computations from database. Undocumented amounts were allotted according to the distribution of documented amounts. Breakdowns for 1930 and 1931, as a result are estimates.

Figure 7 shows a sample of Central European countries. Despite the role of the Bank of England in inflation stabilization in Central Europe, the dollar dominated sterling in the exchange reserves of its central banks after 1924. A temporary exception is 1930, when the National Bank of Czechoslovakia apparently took a bet on sterling at what turned out to be the worst possible time. Thereafter the region participated aggressively in the process of foreign exchange liquidation. With the pound's departure from the gold standard, not just sterling but also dollar reserves were liquidated. ${ }^{54}$ We see also a rise in the role of the French franc which dominates strongly reduced foreign exchange reserves in 1933. Interestingly, when Central European central banks partially rebuilt their foreign exchange reserves, they held sterling rather than dollars. Thus, the resurrection of sterling as the leading reserve currency in the 1930s was not solely a phenomenon of the sterling area. ${ }^{55}$

\footnotetext{
${ }^{54}$ This response on the part of Central European central banks was commented upon by Coste (1932).

${ }^{55}$ There is also a comparatively higher accumulation of French francs (and other currencies) than for other currency groups during the period 1931-33. This is, however a transient phenomenon, and before the Front Populaire was elected, almost all French francs had been sold. It is again amplified by the peculiar behavior of Czechoslovakia. Material for Hungary and Poland (which we are in the process of tracking down) will help determine whether this is an isolated phenomenon.
} 
Figure 8. Non-English-Speaking Sterling Area (millions of USD)

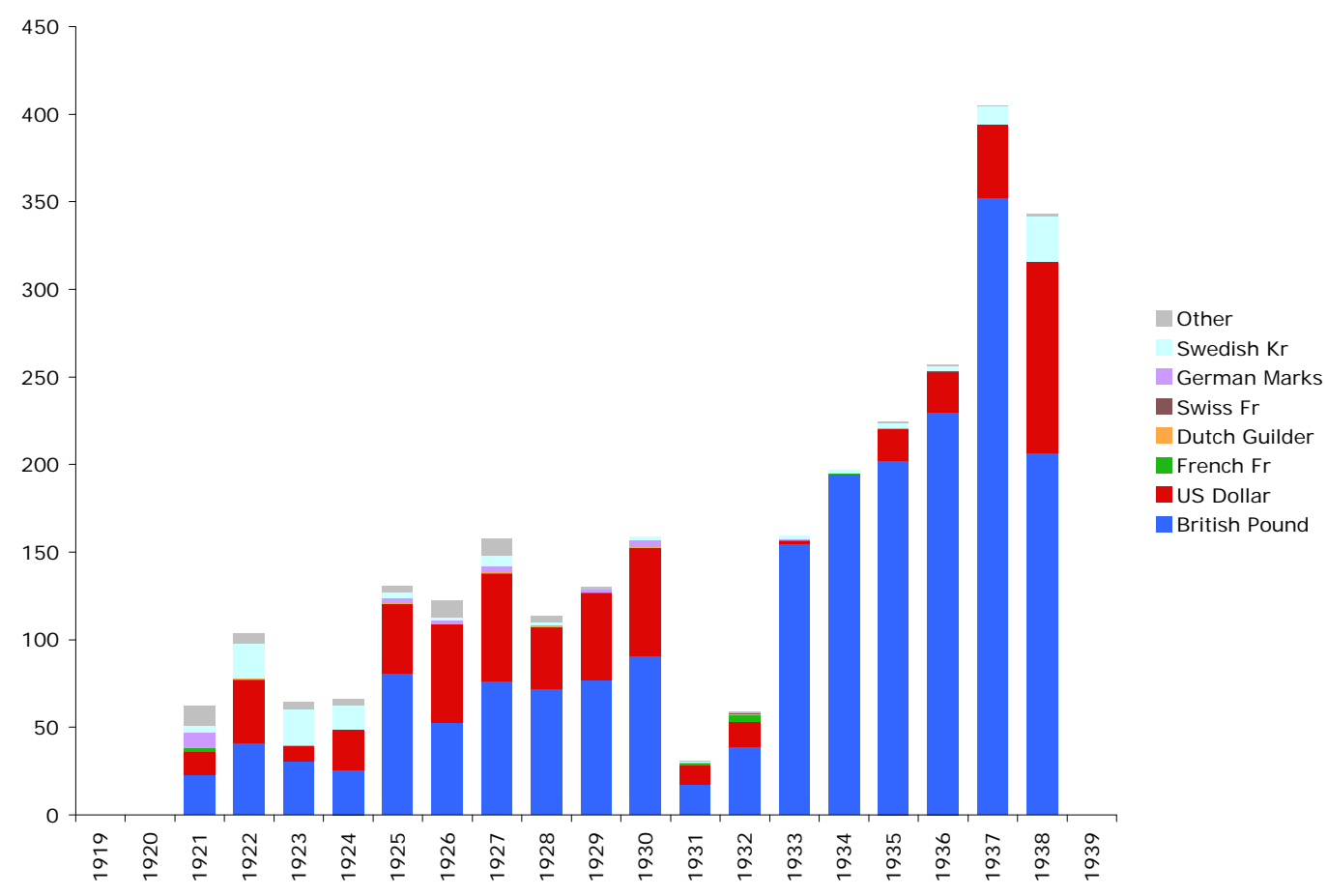

Source: See text. Four Scandinavian countries. Portugal still needs to be added, but as we do not have data for the 1920s at this stage, we were reluctant to apply proportions from Scandinavian countries to Portugal

Figure 8 for the non-English-speaking members of the sterling area (here the Scandinavian nations plus Portugal) is predictable. These countries held both sterling and dollars in the 1920s although, in contrast to the situation in other parts of the world, sterling had an edge that showed no signs of eroding. When sterling holdings recovered in the 1930s, they initially drove the dollar out of the portfolios of these countries entirely. But with the approach of World War II, non-Empire-and-Commonwealth sterling area countries increasingly moved their holdings toward dollars. When the war erupted, most reserves were again in dollars. At that date, the US was a neutral country.

A final European economy is Spain, which never went back on the gold standard and belonged to no currency bloc but nonetheless held more than $\$ 50$ million of exchange reserves in 1930-31. As for our other countries, it is evident (Figure 9) that the dollar overtook sterling as a reserve currency, but the timing for Spain is different. ${ }^{56}$ The dollar gains ground on sterling later than in other countries, and there is no evidence of it giving back ground in the 1930s. The contrast with Portugal, a member of the sterling area, is striking. (See appendix.) Again, we only find traces of French francs, despite the fact that the Bank of France was being used as a repository for Spanish gold. ${ }^{57}$

\footnotetext{
${ }^{56}$ As is the case for all Spanish international monetary matters between the wars.

${ }^{57}$ See Acena (2006).
} 
Figure 9. Spain (US \$ m.)

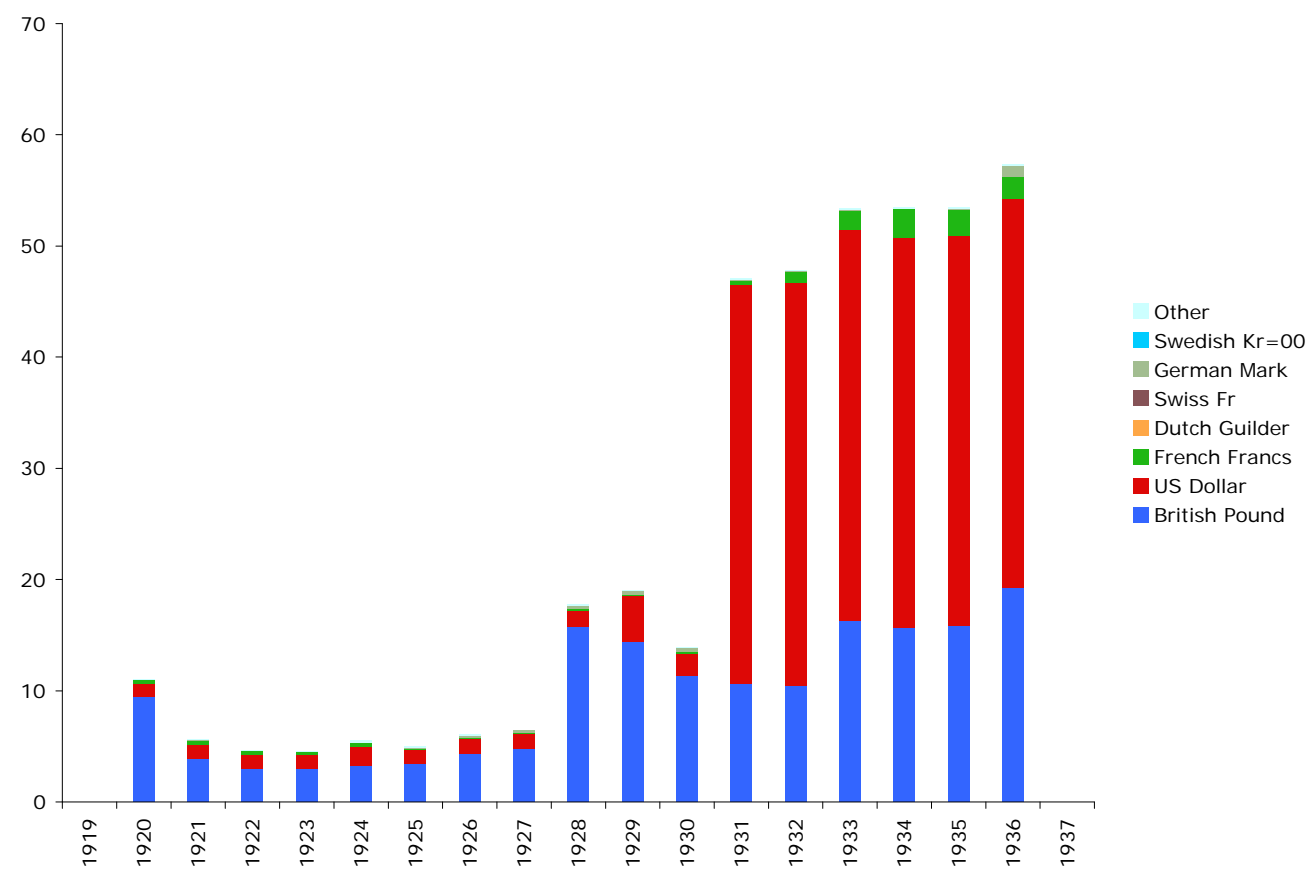

Figure 10. Latin America (Chile and Colombia, millions of USD)

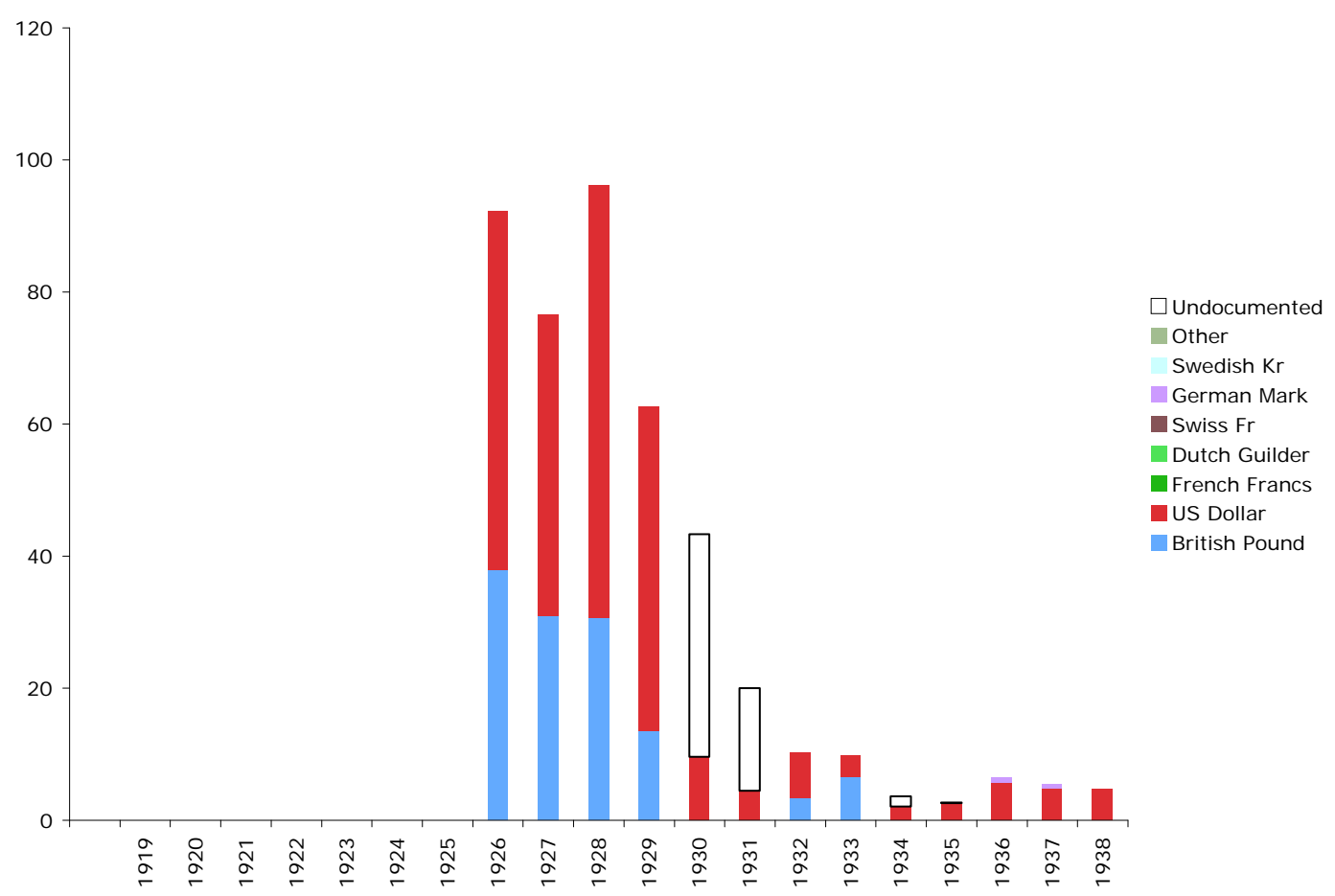

Source: See text. We suspect that actual estimates would be very influenced by which countries would be added. Having complete data for Brazil would raise the share of sterling; Data for Argentina might increase the US dollar's share, and so on. 
Figure 10 shows Latin America. There too the U.S. dollar had become the dominant reserve currency already in the mid-1920s, inconsistent with the idea that inertia, incumbency and network effects rule the day. There too, however, sterling retained substantial market share, inconsistent with the notion that there is only room for one dominant reserve currency. Come the 1930s, both Chile and Colombia reduced their holdings of foreign exchange relative to gold, and Chile, suffering from a large adverse terms-of-trade shock, experienced a large loss of reserves overall. Colombia for its part continued to hold its foreign exchange reserves primarily in the form of dollars. Alas, at this point we have data for too few Latin American countries in the 1930 s to hazard generalizations.

Figure 11. Japan (millions of USD)

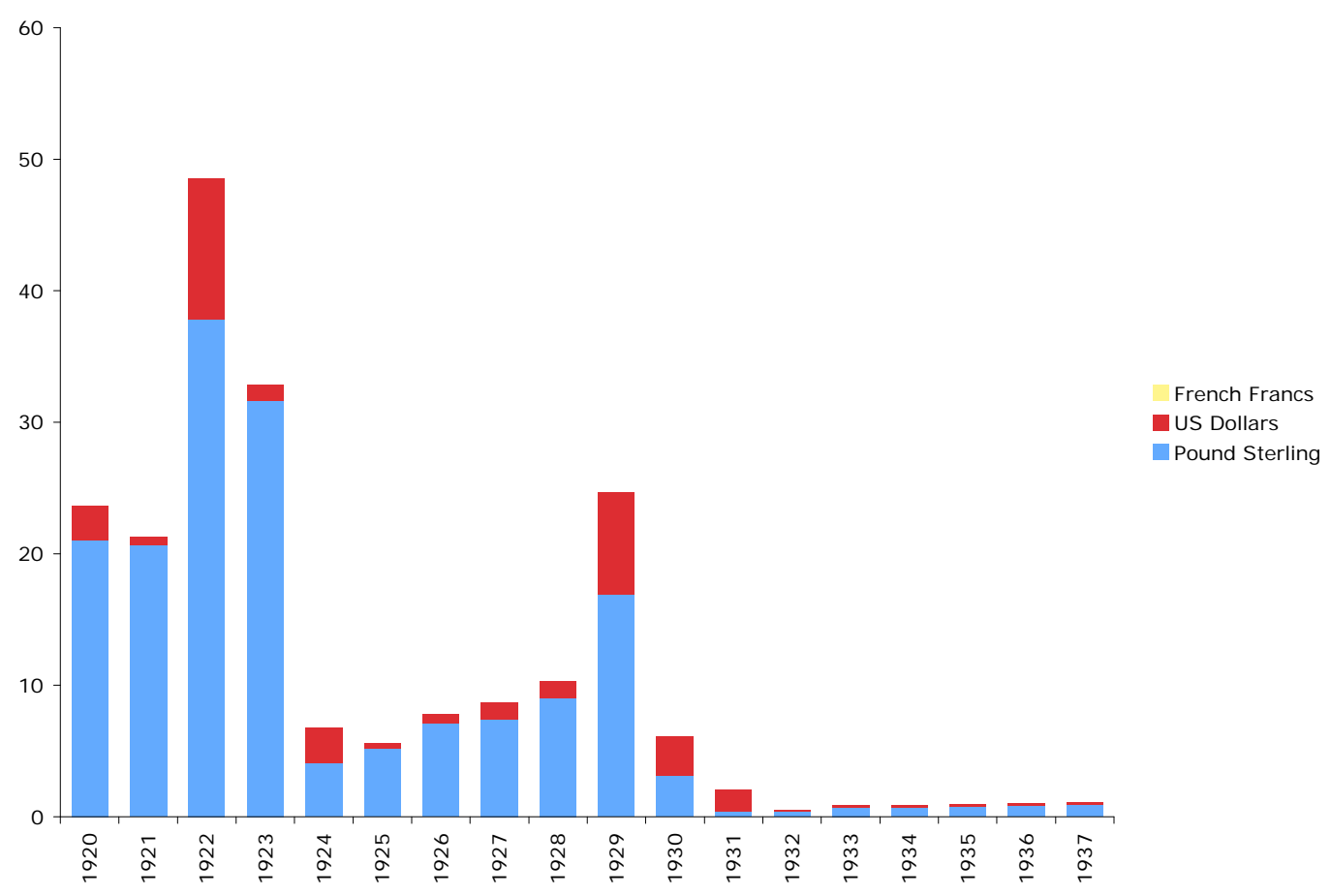

A final country for which we have information is Japan (Figure 11). The Bank of Japan already held large foreign exchange reserves in the 1920s despite only going back onto the goldexchange standard in 1930. Although the composition of the part it held for its own account, on which we focus, is volatile, certain features are clear. ${ }^{58}$ The dollar and sterling were the two dominant forms of exchange reserves, supplemented by some marginal holdings of French francs. The dollar dominated the Bank's portfolio in the immediate aftermath of World War I and in 1929-32. Thereafter the Bank of Japan drastically reduced its exchange reserves; as in other countries, sterling and not the dollar dominated in the 1930s

\footnotetext{
58 The second appendix shows an alternative series including both reserves held on the Bank's own account and on behalf of the government. This alternative is more consistent with our general story.
} 


\section{Implications}

Our findings have implications for reserve-currency competition, for interwar economic and financial history, and for the future. The conventional wisdom on reserve-currency competition, epitomized by Triffin, is that sterling remained the dominant reserve currency throughout the interwar period despite the fact that the United States had recently overtaken the United Kingdom as the dominant economic, commercial and financial power. This is seen as testifying to the advantages of incumbency, the extent of inertia, the power of network effects, and the fact that there is room for only one dominant unit in the international currency domain. But even strong lock-in can become unlocked. Once the economic and commercial imbalance between the two countries swung decisively toward the United States after World War II, there then occurred an irreversible switch from sterling to the dollar.

Our findings challenge every element of this conventional account. The dollar in fact displaced sterling as the leading reserve currency already in the mid-1920s, not only after World War II. Evidently inertia is less than sometimes supposed. Indeed, the status of dominant currency, once lost, was not lost forever; sterling again surpassed the dollar as the leading reserve currency in the 1930s. This revival helps to explain how authors like Triffin, generalizing from the late 1930s, could think that sterling reined supreme in the 1920s. It is also a reminder that reserve-currency status depends on more than just economic, commercial and financial size. ${ }^{59}$ It also depends on politics - the politics of the sterling area explaining, in our case, why the pound and not the dollar was the main form in which exchange reserves were held after both the U.S. and UK devalued their currencies.

Indeed, our findings challenge the very notion that there necessarily exists a "dominant" reserve currency. They throw into question the idea that network effects and external scale economies leave room for only one significant international currency. A reasonable reading of the evidence is that sterling and the dollar shared reserve-currency status in the interwar period. Both New York and London were liquid financial markets. Neither the U.S. nor the UK had significant capital controls. ${ }^{60}$ Both were attractive places to hold reserves. As a group, central banks split their reserves between them, not wishing to put all their eggs in one basket. This was not dissimilar from prevailing practice before World War I. The real anomaly is, rather, the period after World War II, when American economic and financial dominance was overwhelming, New York was the only truly deep and liquid financial market, and the U.S. was only country to shun capital controls - and when the dollar, therefore, dominated the reserve holdings of central banks. ${ }^{61}$

But the fact that there was room in central bank portfolios for more than one reserve currency in the 1920s and 1930s does not mean that there was room for an unlimited number. The third aspirant to reserve-currency status, the French franc, never played more than a minor role. A substantial contemporary literature reports on the efforts of the French government and the Bank of France to build up Paris as a reserve and-international financial center in the 1930s. Authors like Mlynarski (1929) Einzig (1931), Coste (1932), Nathan (1938) and Nurkse (1944) portray Paris as third behind New York and London as an international reserve center. Our

\footnotetext{
${ }^{59}$ The main factor emphasized by Chinn and Frankel (2008).

${ }^{60}$ The UK maintained some limited controls on long-term foreign lending by residents, but these were largely irrelevant from the standpoint of the present issues.

${ }^{61}$ Even the panoply of controls introduced in the 1960s did not apply to foreign central banks. Arrangements like the Gold Pool were designed to limit the access of such central banks to their dollar reserves but proved largely ineffectual (Eichengreen 2006).
} 
findings suggest that even this characterization is overly polite. Before 1928, the year of France's de jure stabilization, the question was moot. And by 1933, when both the U.S. and UK were off the gold standard and their currencies were fluctuating, France too had developed serious economic and financial problems. Awareness that France might be forced to follow the U.S. and UK off the gold standard made Paris a less than attractive place to hold reserves. ${ }^{62}$ One is tempted to draw parallels with efforts to make the yen a reserve currency in the 1990s or, perhaps, with talk about whether the Chinese yuan might become a reserve currency in the nottoo-distant future. When a country has serious economic and financial problems, like France in the 1930s, Japan in the 1990s and, not inconceivably, China in the future, acquiring reservecurrency status is even more difficult than holding onto it.

Nurkse (1944, p. 46 et seq.) recognized that sterling and the US dollar shared the market in the 1920s and portrayed this situation as unstable. He argued that it encouraged central banks to shift their reserves from one center to another at the first sign of trouble, adding central banks to his list of destabilizing speculators. He also suggested that the existence of other centers such as Paris created additional tensions. ${ }^{63}$ Our evidence is not inconsistent with the first point in that it shows sharp changes in foreign exchange composition on the portfolios of a variety of central banks after 1929. But it suggests that Nurkse made too much of the "French option," in that the franc never really constituted a meaningful alternative to sterling and the dollar. Conversely, this casts doubts on a large literature that has put much blame on France's ambitions to recover financial clout. One cannot having both ways: France was small fry and its role should not be overstated.

A final question is what this episode tells us about the future and specifically about the danger of a scramble out of dollar reserves. As we write, foreign central banks are growing anxious that a further decline in the dollar and U.S. credit problems might result in additional capital losses on their dollar balances. And today, just as in the 1930s, there exists an alternative reserve asset, namely the euro, issued by a large economy possessing deep and liquid financial markets. Interwar history suggests that the possibility of a sharp shift in reserve composition cannot be discounted in such circumstances. If there is a large-scale shift from dollars to euros, it is not inconceivable that the Fed could feel compelled to raise interest rates to support the dollar exchange rate and limit imported inflation. Forcing the central bank into this corner would not be helpful in a period when recession and deflation are in the air. If the dollar falls further, the euro will rise further. ${ }^{64}$ In this case Europe too may feel deflationary pressure. The consequences would not be unlike those in 1931, when Britain's devaluation transmitted deflationary pressure to the United States. And if the parallel is to be extended, we note that sterling problems eventually became serious dollar troubles.

But there are also differences between the two periods. In 1931 the scramble out of sterling was not a scramble into the dollars; rather, it was a scramble into the third reserve asset, gold. The United States saw its currency weaken, forcing the Fed to raise interest rates, rather than strengthening as in the European scenario in the preceding paragraph. But imagine, for sake of argument, that economic and financial problems comparable to those in the United States also

\footnotetext{
${ }^{62}$ Foreign banks simply used the Bank of France as a place to store gold and cashed it in when circumstances changed.

${ }^{63}$ The BIS report of 1932 (in many ways it was a source of inspiration to Nurkse) shares the same view, arguing that before WWI, "there was only one reserve center for the gold exchange standard and none of the difficulties resulting from the multiple reserve system of the post-War period were extant.

${ }^{64}$ By definition.
} 
infect Europe, as happened in the 1930s. Asian and Latin American central banks might then wish to scramble out of both dollar and euro securities in a 1931-style scenario. The question is where they would go. Just as there was no viable third option in the 1930s, there is no obvious third option now: there are not enough Swiss francs to go around. Central banks could scramble into gold as a safe haven, mimicking the behavior of private investors. This would create credit stringency in both the U.S. and Europe, as in the 1930s. Working against this is the observation that gold is already expensive and no longer enjoys its historic stature as a reserve asset. ${ }^{65}$

This suggests that if central banks and governments want to shift out of both U.S. and European securities, they are more likely to shift into claims on real assets other than gold, for example purchasing equities through their sovereign wealth funds. The consequences for the U.S. and European economies would not then be so damaging. Of course, this scenario for how central banks will respond assumes their confidence in the fundamental health of the U.S. and European economies. It assumes, in other words, that economic and financial circumstances today, however dire, still do not begin to approach those of the Great Depression.

\footnotetext{
${ }^{65}$ While the present authors regard this as implausible, Steil and Hinds (2008, chapter 7, p.36) suggest that "if the dollar's recent woes were to persist...central banks might well start accumulating gold again. This would, of course, further drive up the price of gold. Yet since a rising gold price would not be experienced on the central bank ledgers as a depreciation of their dollar assets (which are measured against other currencies), diversification into gold would actually be more politically palatable than diversification into euros and other currencies.
} 


\section{References}

Accominotti, Olivier (2008), “The Sterling Trap: Foreign Exchange Reserve Management at the Bank of France During the Gold Standard, 1928-1936,” unpublished manuscript, Sciences-Po.

Aliber, Robert Z. (1966), The Future of the Dollar as an International Currency, New York: Frederick Praeger.

Bank of International Settlements, Monetary and Economic Department (1932), “The Gold Exchange Standard”, Mimeographed document, Basel.

Bernanke, Ben (1995), “The Macroeconomics of the Great Depression,” Journal of Money, Credit and Banking 27, pp.1-28.

Bloomfield, Arthur I. (1963), Monetary Policy under the International Gold Standard: 18801914, New York: Federal Reserve Bank of New York.

Cassel, Gustav (1928), Postwar Monetary Stabilization, New York: Columbia University Press.

Cassell, Gustav (1930), “The Supply of Gold,” in First Interim Report of the Gold Delegation of the League of Nations, Geneva: League of Nations, Annex X.

Cassell, Gustav (1936), The Downfall of the Gold Standard, London: Frank Cass \& Co. Ltd.

Chinn, Menzie and Jeffrey Frankel (2008), “The Euro May over the Next 15 Years Surpass the Dollar as the Leading International Currency,” International Finance (forthcoming).

Choudhri, Ehsan and Levis Kochin (1980), “The Exchange Rate and the International Transmission of Business Cycle Disturbances: Some Evidence from the Great Depression,” Journal of Money, Credit and Banking 12, pp. 565-574.

Coste, Pierre (1932), La lutte pour la suprématie. Les grands marchés financiers, Paris, Londres, New York, foreword by Pierre Quesnay, Paris : Payot.

Eichengreen, Barry (2006), Global Imbalances and the Lessons of Bretton Woods, Cambridge, Mass.: MIT Press.

Eichengreen, Barry and Jeffrey Sachs (1985), "Exchange Rates and Economic Recovery in the 1930s,” Journal of Economic History 45, pp.925-946.

Eichengreen, Barry and Jeffrey Sachs (1986), “Competitive Devaluation and the Great Depression: A Theoretical Reassessment,” Economics Letters 22, pp. 67-71.

Einzig, Paul (1931), Behind the Scenes of International Finance, London: Macmillan. 
Einzig, Paul (1935), World Finance 1914-1935, London: Macmillan.

Emden, Paul H. (1938), Money Powers of Europe in the Nineteenth and Twentieth Centuries, New York: D. Appleton.

Federal Reserve Board (1943), Monetary Statistics of the United States, Washington, D.C.: Board of Governors of the Federal Reserve System.

Flandreau, Marc and Francois Gallice (2005), "Paris, London and the International Money Market: Lessons from Paribas, 1885-1913,” in Eric Bussiere and Youssef Cassis (eds), London and Paris as International Financial Centers in the $20^{\text {th }}$ Century, Oxford: Oxford University Press, pp.78-106.

Flandreau Marc and Nathan Sussman (2003), "Old Sins: Exchange Clauses and European Foreign Lending in the $19^{\text {th }}$ Century," in Barry Eichengreen and Ricardo Hausman (eds), Other People's Money: Debt Denomination and Financial Instability in Emerging Market Economics, Chicago: University of Chicago Press, pp. 154-189.

Friedman, Milton and Anna Schwartz (1963), A Monetary History of the United States, 18631960, Princeton: Princeton University Press.

Gayer, Arthur D. (1937), Monetary Policy and Economic Stabilisation: A Study of the Gold Standard, New York: Macmillan.

Gregory, T.E. (1932), The Gold Standard and its Future, New York: E.P. Dutton \& Co.

Hamilton, James (1988), “The Role of the Gold Standard in Propagating the Great Depression,” Contemporary Policy Issues 6, pp.67-89.

Hatase Mariko and Mari Ohnuki (2008), "Foreign Reserve Management for Japan as a Developing Country during the Interwar Period: Its Investment Behaviour Selection of Assets and Choice of Currency”, Paper prepared for PPP3, Genoa, March 2008.

Hawtrey, Ralph (1923), Monetary Reconstruction, London: Longmans.

Johnson, Clark (1997), France, Gold and the Great Depression, New Haven: Yale University Press.

Keynes, John Maynard (1923), A Tract on Monetary Reform, London: Macmillan.

Keynes, John Maynard (1925), The Economic Consequences of Mr. Churchill, London: Macmillan.

Kindleberger, Charles (1967), "The Politics of International Money and World Language,” Essays in International Finance no. 61, International Finance Section, Department of Economics, Princeton University. 
Kiyotaki, Nobu and Randall Wright (1989), “On Money as a Medium of Exchange”, Journal of Political Economy, Vol. 97, pp. 927-954.

Kooker, Judith (1976), “French Financial Diplomacy: The Interwar Years,” in Benjamin M. Rowland (ed.), Balance of Power or Hegemony: The Interwar Monetary System, New York: New York University Press, pp.83-146.

Krugman, Paul (1980), "Vehicle Currencies and the Structure of International Exchange,” Journal of Money, Credit and Banking 12, pp. 513-26.

Krugman, Paul (1984), “The International Role of the Dollar: Theory and Prospect,” in J. F. O. Bilson and R. C. Marston (eds), Exchange Rate Theory and Practice, University of Chicago Press, pp.**_**.

Lewis, C., (1938), America's Stake in International Investments, Washington, DC: Brookings Institution.

Lindert, Peter H. (1969), “Key Currencies and Gold, 1900-1913,” Princeton Studies in International Finance no. 24, International Finance Section, Department of Economics, Princeton University.

Maddison, Angus (2001), Monitoring the World Economy, Paris: OECD.

Margairaz, Michel (200*), “La SDN, les banques d’émission et les statistiques monétaires entre les deux guerres”, in Feiertag and Margairaz, eds., Mesurer la monnaie,

Melchior Palyi (1972), The Twilight of Gold, Chicago: Henry Regnery.

Mlynarski, Feliks (1929), Gold and Central Banks, New York: Macmillan.

Moggridge, Donald (1969), The Return to Gold, 1925, Cambridge: Cambridge University Press.

Mouré, Kenneth (1996), Managing the France Poincare, Cambridge: Cambridge University Press.

Mouré, Kenneth (2002), The Gold Standard Illusion: France, the Bank of France, and the International Gold Standard 1949-1939, Cambridge: Cambridge University Press.

Mundell, Robert (2000), “A Reconsideration of the Twentieth Century,” American Economic Review 90, pp.327-340.

Myers, Margaret (1936), Paris as a Financial Center, London: P.S. King.

Nathan, Roger (1938), Le rôle international des grands marchés financiers, Publications de l’Institut des Hautes Etudes Internationales, Genève, Paris: Sirey. 
Nurkse, Ragnar (1944), International Currency Experience, Geneva: League of Nations.

Pasvolsky, Leo (1933), Current Monetary Issues, Washington, D.C.: The Brookings Institution.

Rist, Charles, (1933), Essais sur quelques problemes economiques et monetaires, Paris: Sirey.

Schuler, Kurt (1992), Currency Boards, unpublished Ph.D. dissertation, George Mason University.

Steil, Benn and Manuel Hinds (2008), Money, Markets and Sovereignty, unpublished manuscript, Council on Foreign Relations.

Temin, Peter (1989), Lessons from the Great Depression, Cambridge, Mass.: MIT Press.

Temin, Peter and David Vines (2008), “Gold Scarcity and the Great Depression,” unpublished manuscript, MIT.

Triffin, Robert (1960), Gold and the Dollar Crisis, New Haven: Yale University Press. 


\section{Appendix 1: The Global Gold Shortage}

In this appendix we look again at the global gold shortage that provided the motivation for the Genoa resolutions. ${ }^{66}$ With benefit of hindsight we now know that this shortage was not as severe as anticipated. Where global output of goods and services was approximately 20 per cent higher in 1925 than it had been in 1913-4, global gold reserves were almost 70 per cent higher. ${ }^{67}$ This meant that commodity prices could remain as much as 50 per cent above prewar levels without creating a gold shortage and credit squeeze. While contemporaries were preoccupied by the fall in gold production during and after the war, the fact was that production was still running at more than double industrial consumption. Central bank gold reserves were further augmented, both during and after the war, by withdrawing gold coin from circulation and concentrating it at central banks. With this move from a gold coin standard to a gold-exchange standard, only a fraction of the domestic circulation had to be fully backed with gold. As a result, the same amount of gold effectively went farther. ${ }^{68}$

The U.S. price level was 40 per cent higher in 1925 than it had been in $1913 .{ }^{69}$ To the extent that reserves flowed toward the U.S. in the second half of the 1920s (the country was in balance of payments surplus), it is fair to think of the dollar as somewhat undervalued relative to other currencies; equivalently, one may think of price levels as having risen a bit more than this (relative to currencies) in other parts of the world. ${ }^{70}$ But even if the dollar was 10 to 15 per cent undervalued - that is, even if the overvaluation attributed to the pound sterling, the most clearly overvalued currency, is generalized to other currencies - there is still an absence of clear evidence of a global gold shortage. $^{71}$ If the U.S. price level had risen by 40 per cent and prices elsewhere had risen by 55 per cent, and if the U.S. was a quarter of the world economy, then price levels worldwide would have been 51 per cent higher than

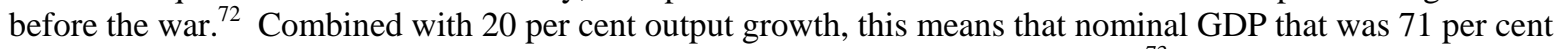
higher. Recall that central bank gold reserves rose by 70 per cent over the period. ${ }^{73}$

Nor was it obvious that this problem would worsen. With gold production outstripping industrial consumption, gold reserves grew at an annual rate of 3.4 per cent per annum in the four years 1926-29, matching the growth of global output. $^{74}$ This in fact exceeded the 3 per cent per annum figure that even gold-shortage advocates like Gustav Cassell argued would be needed to keep prices from falling. ${ }^{75}$ Some authors anticipated faster growth of output and trade (in particular linking the growth of the demand for international reserves to the growth in trade). In the event, this did not come about.

Thus, if there was a problem to be solved by the further spread the gold-exchange standard, it was not a problem of gold shortage but rather a problem of gold distribution. Gold reserves were disproportionately concentrated in the coffers of two central banks: the Federal Reserve and the Bank of France. ${ }^{76}$ With these two central banks holding more gold than needed to back their monetary circulation, less was available to other countries, requiring them to augment their gold reserves with foreign exchange or undergo further deflation. By 1929, these two countries together held more than 50 per cent of the world's monetary gold. This, then, was the nature of the problem that to which the gold-exchange standard was a response.

\footnotetext{
${ }^{66}$ Which has been given new prominence by Johnson (1997), Mundell (2000) and Temin and Vines (2008).

${ }^{67}$ The comparison of global output in 1913 and 1925 is based on Maddison's (2001) figures for 1913 and 1929 and our estimate of 3 per cent annual growth from 1925 through 1929. Figures on the global gold stock are from Nurkse (1944), Appendix I.

${ }^{68}$ Triffin (1968), p.42 estimates that the withdrawal of gold coin from circulation accounted 44 per cent of the growth of central bank gold reserves between 1914 and 1928 (new gold production accounting for the rest).

${ }^{69}$ And world trade was five per cent higher.

${ }^{70}$ Recall that a situation where prices rise faster than the exchange rate is one of real appreciation; the currency of the country in question is "overvalued" relative to its trading partner (in this case, relative to the United States).

${ }^{71} 10$ to 15 per cent is in the ballpark of estimates for sterling overvaluation provided by, inter alia, Moggridge (1969).

${ }^{72}$ Feliks Mlynarski’s estimate, writing in 1928, was 50 per cent; Mlynarski (1929), p.6.

${ }^{73}$ So much for the gold shortage. Other comparisons of the second half of the 1920s with 1913 - in terms of the ratio of central bank liabilities to monetary gold or the sum of central band commercial bank liabilities to monetary gold - are analyzed in Gregory (1932), Gayer (1937) and Palyi (1972), who reach the same conclusion that we do.

${ }^{74}$ Recall that the price level was basically stable.

${ }^{75}$ Famously in Cassell $(1928,1930)$.

76 This was the problem that contemporaries referred to as "gold maldistribution."
} 
Table 1. Coverage

\begin{tabular}{|c|c|c|c|}
\hline Country & Source & Period & Valuation \\
\hline \multicolumn{4}{|c|}{ Gold Bloc Countries } \\
\hline France & Bank of France & 1928-39 & Market Exchange rates \\
\hline Italy & Collana Storica & 1920-39 & Market Exchange Rates \\
\hline Switzerland & Swiss National Bank & 1920-39 & \\
\hline Netherlands & Bank of the Netherlands & 1920-1931 & Market Exchange Rates \\
\hline \multicolumn{4}{|c|}{ Central Europe } \\
\hline Austria & Bank of Austria & 1923-29, 1932-7 & Market Exchange Rates \\
\hline Czechoslovakia & Bank of Czechoslovakia & $1921-38$ & Market Exchange Rates \\
\hline Romania & Bank of Romania & 1929-34, 1937 & Market Exchange Rates \\
\hline \multicolumn{4}{|c|}{ Sterling Area } \\
\hline Denmark & Bank of Denmark & 1919-1939 & Book Exchange Rates \\
\hline Finland & Bank of Finland & 1921-1938 & Book Exchange Rates \\
\hline Norway & Bank of Norway & 1920-1939 & Book Exchange Rates \\
\hline Portugal & Bank of Portugal & 1931-1939 & Book Exchange Rates \\
\hline Sweden & Riksbank & 1926-1939 & Market Exchange Rates \\
\hline \multicolumn{4}{|c|}{ Other Europe } \\
\hline Spain & Bank of Spain & $1920-1936$ & Market Exchange Rates \\
\hline \multicolumn{4}{|c|}{ Latin America } \\
\hline Brazil & $\begin{array}{l}\text { Reports of the Caixa de } \\
\text { Estabilização }\end{array}$ & $1927-29$ & $\begin{array}{l}\text { Book values coincide with fixed } \\
\text { exchange rate prevailing during } \\
\text { available dates }\end{array}$ \\
\hline Colombia & Bank of Chile & $\begin{array}{l}1926-29,1932- \\
33,1936-39 \\
\end{array}$ & Market Exchange Rates \\
\hline Chile & Bank of the Republic & $1923-1939$ & Market Exchange Rates \\
\hline \multicolumn{4}{|c|}{ Asia } \\
\hline Japan & Bank of Japan & $1920-1939$ & Market Exchange Rates \\
\hline
\end{tabular}

Source: See text; Italy counted as member of Gold Bloc . 
Appendix 2:

Japan: Gold and Foreign Exchange on Own Account and on Behalf of the Government (millions of yen)

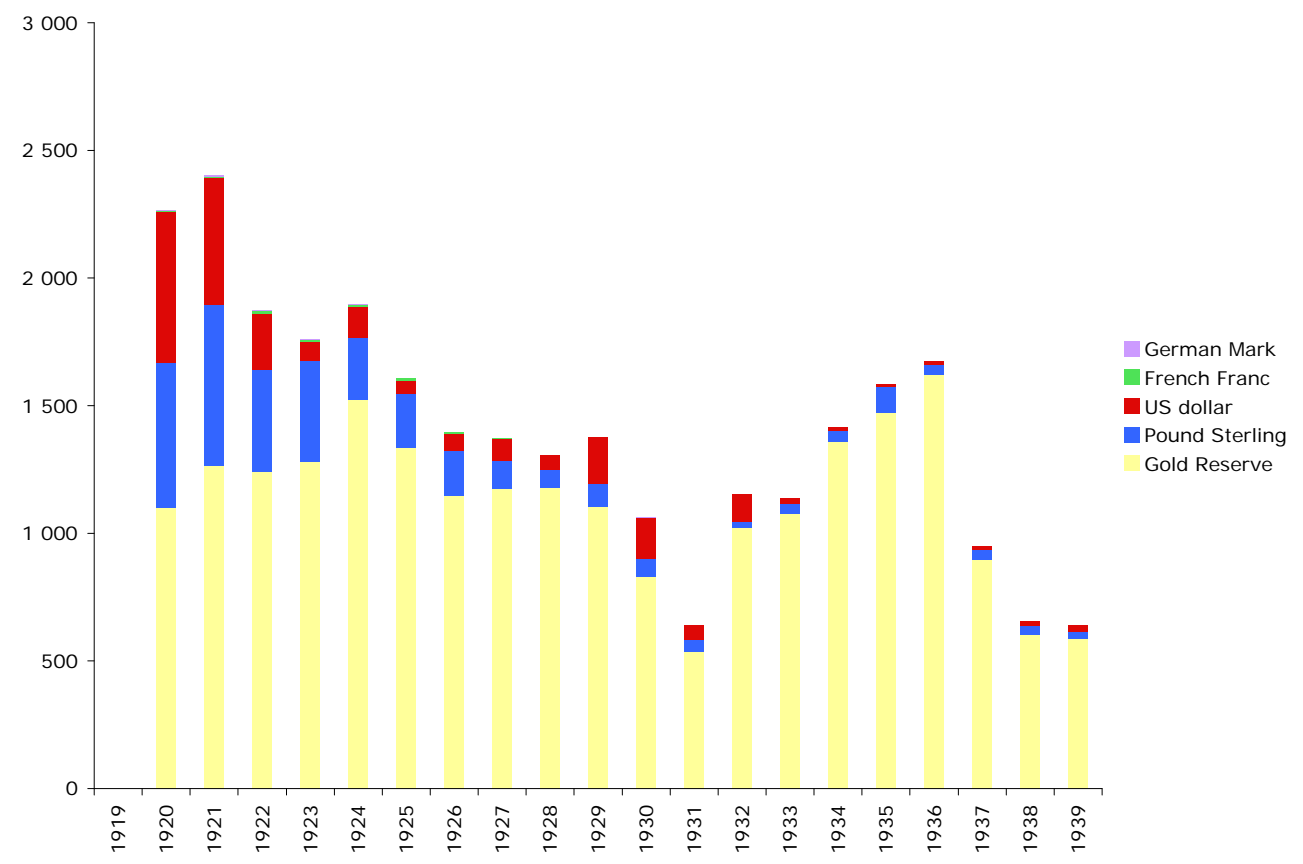

